\title{
Innovation and borrower discouragement in SMEs
}

\author{
Ross Brown $\mathbb{1} \cdot$ José M. Liñares-Zegarra • \\ John O.S. Wilson
}

Accepted: 12 November 2021 / Published online: 11 January 2022

(C) The Author(s) 2021

\begin{abstract}
In this paper, we investigate whether innovative small- and medium-sized enterprises (SMEs) are more likely to be discouraged from applying for external finance than non-innovators. These so-called discouraged borrowers are credit worthy SMEs who choose not to apply for external finance despite the fact that this is needed. We find that SMEs undertaking pure product and joint product and process innovation have a significantly higher incidence of borrower discouragement than non-innovative counterparts. Moreover, radical and incremental product innovators are more likely to be discouraged relative to non-innovative counterparts. Innovative activity can increase borrower discouragement for a myriad of reasons including fear of rejection, reluctance to take on additional risk, negative perceptions of the
\end{abstract}

Supplementary Information The online version contains supplementary material available at https://doi. org/10.1007/s11187-021-00587-1.

R. Brown $(\bowtie) \cdot$ J. O. Wilson

Centre for Responsible Banking \& Finance, School of Management, University of St Andrews, St Andrews, UK

e-mail: Ross.Brown@st-andrews.ac.uk

J. O. Wilson

e-mail: jsw7@st-andrews.ac.uk

J. M. Liñares-Zegarra

Essex Business School, University of Essex,

Wivenhoe Park, Colchester CO4 3SQ, UK

e-mail: jmlina@essex.ac.uk funding application process and perceived negative economic conditions. Overall, our results suggest a need for targeted policy interventions in order to alleviate borrower discouragement within innovative SMEs, as well as a closer alignment between innovation and SME finance policy.

Plain English Summary Innovative SMEs play a crucial role in driving technological change and productivity growth. Therefore, understanding the factors shaping access to finance for innovative SMEs is of crucial importance to the economy. We investigate the potential impact of innovation activity on the incidence of borrower discouragement, credit worthy firms who choose not to apply for external finance despite the fact that it is required. The results of our empirical investigation suggest that SMEs undertaking pure product and joint product and process innovation have a significantly higher incidence of borrower discouragement than non-innovative counterparts. The principal implication of this study is that innovation is a factor, which self-limits access to finance for innovative SMEs. We offer recommendations to mitigate borrower discouragement in this context.

Keywords Innovation $\cdot$ SMEs $\cdot$ Discouraged borrowers $\cdot$ Access to finance $\cdot$ Public policy

JEL classifications $\quad \mathrm{G} 41 \cdot \mathrm{L} 26 \cdot \mathrm{L} 53$ 


\section{Introduction}

In this paper, we investigate the incidence of borrower discouragement in innovative small- and medium-sized enterprises (SMEs). Innovative start-ups and SMEs are crucial for job creation, innovation and productivity growth (Hall \& Lerner, 2010). A crucial issue facing many innovative SMEs is their ability to access external finance, an issue made even more salient in the wake of the global financial crisis (Lee et al., 2015; Lee \& Brown, 2017). Consequently, how SMEs are financed is a central policy issue given that access to appropriate levels of funding has significant implications for firm growth, performance and long-term survival.

Despite growth in alternative forms of finance such as venture capital, business angel investment and equity crowdfunding in recent years, bank debt continues to represent the primary source of external financing for the vast majority of SMEs (Lee \& Brown, 2017; Robb \& Robinson, 2014). Extant research suggests there are significant structural impediments, in the form of informational asymmetries, asset intangibility and skewed returns, which face innovative SMEs seeking bank funding (Berger \& Udell, 1998; Cassar, 2004). Limited collateral and unstable cash flows further exacerbate access to external bank finance for innovative SMEs (Hall \& Lerner, 2010; Lee et al., 2015). Indeed, negative expectations regarding the likelihood of obtaining external finance can be so acute that some SMEs become discouraged from applying altogether (Cowling et al., 2016). ${ }^{1}$

The prevalent academic definition of borrower discouragement follows Kon and Storey (2003, p.37), where a '...good borrower may not apply for a loan to a bank because they feel they will be rejected.' Due to the nature of many official SME surveys, prior studies adopt (often by necessity) rather restrictive definitions of borrower discouragement-focusing purely on the fear that a loan application is rejected (Neville et al., 2018; Nguyen et al., 2020). For example, survey instruments such as the European Central Bank's Survey on the Access to Finance of Enterprises (SAFE) survey use this somewhat abbreviated definition of discouragement (Calabrese et al., 2020; Mol-Gómez-Vázquez et al., 2021). This is likely to

\footnotetext{
1 The phrase 'why even bother trying' is used to depict this cognitive mind-set (Neville et al., 2018).
}

significantly underestimate the true extent of borrower discouragement across SMEs. Fortunately, the depth of information compiled in the UK Department for Business, Energy and Industrial Strategy (BEIS) Longitudinal Small Business Survey (LSBS) used in this study allows a multi-faceted measure of borrower discouragement to be constructed, which encompasses whether an SME had a requirement for finance in the last 12 months, but did not apply for any of the following reasons: fear of rejection; cost of credit; additional risk-taking; poor credit history; prevailing economic conditions; knowledge of financial sources; and the time and hassle associated with applying. ${ }^{2}$ The mutually exclusive options selected by SME respondents as the reason for not applying for external finance are useful in discerning potential market imperfections (discouraged borrowers) and other reasons that SMEs do not seek credit when required. In this paper, we present novel evidence suggesting that innovative SMEs are significantly more likely to be discouraged from applying for external finance than their non-innovative counterparts.

There are compelling theoretical and policy reasons for investigating the drivers of borrower discouragement, given that these may ultimately lead creditworthy SMEs to forego credit, leading to negative knock-on effects for the real economy via declines in future innovative activity and employment creation. Despite this, discouraged borrowers have until recently been a relatively under researched and neglected cohort of SMEs (Cowling et al., 2016). This is somewhat surprising given these firms significantly outnumber firms that apply for external finance but are subsequently denied credit (Freel et al., 2012; Levenson \& Willard, 2000; Wernli \& Dietrich, 2021). Recent evidence reveals that over half of discouraged borrowers $(55 \%)$ would secure external finance if they had applied for a loan (Cole \& Sokolyk, 2016; Cowling et al., 2016). Prior research suggests that borrower discouragement is driven by a variety of

\footnotetext{
${ }^{2}$ Most empirical studies define borrower discouragement as the fear of being rejected for bank funding. However, the factors shaping discouragement are likely to be heterogeneous and complex. A substantial proportion of SMEs state that they 'don't want to take on additional risk' as a main reason for being discouraged (25.3\%), followed by 'you thought you would be rejected' (15.8\%) and 'it would be too expensive' $(12.7 \%)$. Figure A1 in the appendix provides a full summary.
} 
entrepreneurial and firm-level characteristics. However, to date evidence regarding the impact of innovation on borrower discouragement is scarce, despite a priori expectations that borrower discouragement is likely to be higher amongst innovative SMEs given their informational opacity and the inherent risk and uncertainty of outcomes associated with innovation activity (Hutton \& Nightingale, 2011).

The issue of borrower discouragement is critical given that undercapitalisation during initial phases of a SME's development can lead to subsequent underperformance (Marlow \& Patton, 2005). Therefore, borrower discouragement is clearly important from a public policy perspective (BEIS, 2017; Hutton \& Nightingale, 2011). For example, in the UK, the state-owned British Business Bank and the Scottish National Investment Bank have recently acknowledged the need to tackle SME borrower discouragement (British Business Bank, 2020; Scottish Government, 2019). The European Central Bank has similarly identified borrower discouragement as a problem facing many SMEs (Ferrando \& Mulier, 2015). The US Federal Reserve and government agencies located in various developing economies are also giving this issue increasing attention (Nguyen et al., 2020). ${ }^{3}$ Therefore, the results of an investigation of borrower discouragement are of direct relevance to policymakers tasked with alleviating funding gaps confronting innovative SMEs.

In this paper, we investigate the incidence of borrower discouragement for innovative SMEs using the aforementioned LSBS, commissioned by the BEIS. The LSBS is a large-scale representative annual survey of UK SME owners and managers with annual sample sizes ranging from 6,600 to 15,500 UK SMEs. We conduct an econometric analysis using Heckman probit models to investigate the association between innovation and borrower discouragement. ${ }^{4}$ Firm-level characteristics are also incorporated into our estimable models in order to control for other factors that are likely to affect borrower discouragement.

\footnotetext{
3 https://www.federalreserve.gov/publications/2019-novem ber-consumer-community-context.htm

4 This accounts for possible sample selection bias, given that the propensity of discouraged borrowers versus loan applicants depends upon the probability that firms need credit. This is crucial in the context of innovative firms, given that innovative firms are more likely to seek (need) external finance (Lee et al., 2015).
}

By way of preview, the results of our empirical analysis suggest that innovative SMEs have a significantly higher incidence of borrower discouragement than non-innovative counterparts. The type of innovation carried out affects the incidence of borrower discouragement. Specifically, product innovators and SMEs engaged in a combination of product and process innovation are more likely to be discouraged borrowers than non-innovative counterparts. Our results also suggest that the novelty of innovation is an important driver of borrower discouragement. In particular we find that both radical and incremental product innovators are also more likely to be discouraged borrowers relative to process innovator counterparts. In addition, our results provide evidence that not only fear of rejection is a key driver of borrower discouragement for innovative firms, but also reluctance to take on additional risk, negative perceptions on the funding application process and perceived economic conditions are also likely to be important. The results presented in this study provide new insights for the literature and respond to calls for more research to verify 'the existence, extent and characteristics' of this phenomenon (Fraser, 2014, p. 85).

The remainder of this paper is structured as follows. In Section 2, we review relevant literature. Section 3 outlines the data, definitions and methods. In Section 4, we present and discuss the main results. Section 5 provides further discussion of the results and resultant policy implications emerging from the study.

\section{Relevant literature}

To examine the interconnections between finance, innovation and borrower discouragement, we discuss salient literature regarding the structural issues typically confronting innovative SMEs seeking external finance. We then review the literature on borrower discouragement and its links with firm-level innovative activity.

\subsection{The supply of finance for innovative SMEs}

Schumpeter (1934) was the first to draw connections between innovation and finance. An integral part of the Schumpeterian story is that financial institutions 
play an essential role as facilitators of the innovative efforts undertaken by entrepreneurs (King \& Levine, 1993; Revest \& Sapio, 2012). One of the ways financial markets are believed to play this role is by allocating capital to firms with the greatest potential to implement new processes and to commercialise new technologies (Kerr and Nanda, 2015).

Lee et al. (2015) claim that there are three fundamental theoretical reasons access to finance can be problematic for innovative SMEs. First, the returns to innovation are highly skewed with only a small number of innovations generating significant revenues, while the remainder yield little or no return. Not only does one not know the probabilities associated with outcomes, but even the forms of the potential outcomes are not clear. While increased innovative activity may increase the probability of superior performance, it cannot guarantee it (Coad \& Rao, 2008). Therefore, from a financier's perspective, this makes it significantly harder to evaluate potential innovative projects requiring funding, particularly since often the only way to accurately assess the potential of a particular innovation is to invest in it (Kerr and Nanda, 2015).

Second, given that SMEs have more information regarding the likely success of any innovation, banks cannot accurately estimate the likely returns to innovative investments due to informational asymmetries (Berger \& Udell, 1998; Hall \& Lerner, 2010). These information asymmetries are a significant factor determining borrower discouragement (Kon \& Storey, 2003). On the whole, asymmetric information issues tend to be most acute for SMEs with higher levels of intangible assets (Mina et al., 2013). Consequently, many innovative firms seek finance from specialised financial intermediaries such as business angels and venture capitalists that address asymmetric information issues via ex-ante soft information collection and ex-post performance monitoring (Liberti \& Petersen, 2019; Robb \& Robinson, 2014).

Finally, in such a situation, collateral is an important tool for banks to mitigate these informational asymmetries and thus resolve the credit-rationing problem. However, intangible assets produced by the innovation process may be difficult to value or transfer beyond an individual firm. Typically, large banks rely on objective lending technologies such as small business credit scoring, asset-based lending and fixed-asset lending techniques (Berger \& Udell,
2006). Each of these techniques relies on either the personal or business collateral that the firm can provide to secure the repayment of the loan. Consequently, innovative SMEs without significant tangible or re-deployable assets have insufficient collateral to obtain external finance (Cosh et al, 2009; Hall \& Lerner, 2010).

Due to the aforementioned issues, prior literature supports the view that innovative SMEs have difficulties obtaining bank finance (Hall \& Lerner, 2010; Lee et al., 2015). Freel (2007) find that innovative UK SMEs were less likely to receive bank finance. Schneider and Veugelers (2010) show that the German innovative SMEs view external financing constraints as an important factor in hampering innovation. Whereas large firms can fund innovation via internal cash flows, smaller innovative firms often have insufficient or unpredictable cash flows to service bank loans adequately (Hall \& Lerner, 2010). Recent evidence also suggests that innovative SMEs can be penalised in other ways, for example, being charged higher interest rates for loans than less innovative counterparts (Rostamkalaei \& Freel, 2016). In continental Europe and the USA, there is also evidence suggesting that firms engaged in innovative activities often face substantial external financing constraints (Hall et al., 2016; Kerr \& Nanda, 2015). Innovative SMEs also appear to be more affected by exogenous liquidity shocks. For example, evidence for Brazil (Paunov, 2012) and the UK (Lee et al., 2015) suggests that innovative SMEs were more likely to be turned down for finance in the aftermath the global financial crisis.

\subsection{Borrower discouragement}

In a seminal contribution, Kon and Storey (2003) outline how actual or perceived barriers to accessing external finance may deter SMEs from applying for credit altogether-so-called discouraged borrowers. Prior evidence suggests that there are significant variations in borrower discouragement across countries (Macan Bhaird et al., 2016; Qi and Nguyen, 2021). Rostamkalaei et al. (2018) report that the incidence of SME borrower discouragement varies between 1 and 45\%. In most developed economies, borrower discouragement affects between 10 and 20\% of SMEs (Christensen \& Hain, 2014; Cowling et al., 2016; Freel et al., 2012; Mac an Bhaird et al., 2016; 
Rostamkalaei et al., 2018). For example, Calabrese et al. (2020) find that $6.5 \%$ of SMEs from a number of EU countries are discouraged borrowers. The incidence of borrower discouragement is significantly higher in developing countries (Chakravarty and Xiang, 2013). Intra-country variations in borrower discouragement are also prevalent. For example, in the UK, Fraser (2004) and Freel et al. (2012) find that approximately $8 \%$ of SMEs are discouraged borrowers, while Cowling et al. (2016) and Rostamkalaei (2017) find a prevalence of borrower discouragement of $2.7 \%$ and $2.1 \%$, respectively.

The results of previous research suggest that borrower discouragement is associated with various entrepreneurial and firm-level traits. Gender differences, age and ethnicity are also important factors which relate directly to the ongoing debate regarding the democratisation of entrepreneurial finance across under-represented groups of entrepreneurs (Cumming et al., 2021). The entrepreneurial and personal characteristics associated with a higher incidence of borrower discouragement include inter alia ethnic minorities (Cavalluzzo et al., 2002; Fraser, 2009), female-led (Cowling et al., 2016; Freel et al., 2012; Moro et al., 2017), older (Cole \& Sokolyk, 2016), less well-educated (Cole \& Sokolyk, 2016; Nguyen et al., 2020) and less wealthy entrepreneurs (Han et al., 2009). Evidence emanating from the USA suggests that socio-historical experiences and shared knowledge of inequalities within certain racial minorities (e.g. African Americans, Hispanic Americans and Asian Americans) may influence borrower discouragement (Neville et al., 2018). Nguyen et al. (2020) show that firms with wider business networks suffer less information asymmetries and consequently are less likely to be discouraged. Serial entrepreneurs are also much more likely to be discouraged borrowers (Freel et al., 2012). Han et al. (2009) find that riskier individuals have a higher incidence of borrower discouragement. Cowling et al. (2016) find that since the global financial crisis, experienced entrepreneurs are more likely to be discouraged borrowers.

In terms of firm-level characteristics, smaller and younger SMEs are significantly more likely to be discouraged borrowers (Han et al., 2009; Freel et al., 2012; Chakravarty and Xiang 2013; Cowling et al., 2016; Mac an Bhaird et al., 2016; Rostamkalaei, 2017). Clearly, newly born firms will have less experience in the credit market and may self-ration as a result of this inexperience (Calabrese et al., 2020). Therefore, in line with a priori theoretical expectations, the smallest most informationally opaque SMEs encounter the greater levels of borrower discouragement (Berger \& Udell, 1998; Cowling et al., 2016). Such SMEs are less likely to have established relationships with lenders (Rostamkalaei et al., 2018). SMEs that have established banking relationships are less likely to discouraged borrowers (Freel et al., 2012). This suggests that established firm-bank relationships facilitate information exchange between borrowers and lenders (Cowling et al., 2016).

The considerable variation in aggregate levels of borrower discouragement reported in prior literature is likely to stem from differences in definitions used. This suggests that considerable caution should be exercised when drawing direct comparisons across studies regarding the incidence of borrower discouragement. Most previous studies typically view borrower discouragement as a binary choice between borrowers who fear rejection and those who do not and consequently have failed to assess the strength or depth of borrower discouragement. This is rather surprising given the multi-dimensional nature of this cognitive phenomenon.

Table 1 highlights the various definitions used in prior studies of borrower discouragement. It also suggests that the definitions of borrower discouragement and how it is examined need to be clearly articulated and delineated when exploring the concept empirically. Overall, there appear to be a complex mix of inter-related factors shaping borrower discouragement in SMEs (Freel et al., 2012). However, owing to this pervasive borrower heterogeneity, perhaps unsurprisingly, within the literature, there are definitional ambiguities in relation to the precise nature of the underlying causes of discouragement. In most surveys, questions relate to whether SMEs enact selfimposed credit constraints for fear of rejection. However, in some surveys, the terms and conditions (collateral and covenants) are also included as reasons for borrower discouragement (Chakravarty and Xiang 2013; Cowling et al., 2016). The range and scope of definitions of borrower discouragement are broader and more inclusive in some survey questionnaires and studies of borrower discouragement than others. Borrowing costs (interest rates, overdraft charges) are also likely to play a role in mediating the demand for finance. A formal loan application can also be costly 
Table 1 Definitions of borrower discouragement used in previous studies

\begin{tabular}{ll}
\hline Study & Data source \\
\hline Nguyen et al. (2020) & $\begin{array}{c}\text { Survey of Small and Medium-Sized Enterprises } \\
\text { in Vietnam }\end{array}$ \\
Rostamkalaei et al. (2018) & UK SME Finance Monitor
\end{tabular}

Technical definition of a discouraged borrower

Gama et al. (2017)

EDRB and World Bank Group's Business Environment and Enterprise Performance Survey (2008/09 BEEPS)

Moro et al. (2017)

Neville et al. (2018)

Tang et al. (2017)

Cole and Sokolyk (2016)

Cowling et al. (2016)

Mac an Bhaird et al. (2016)

Christensen and Hain (2014)

Chakravarty and Xiang (2013) World Bank Enterprise Surveys

Freel et al. (2012)

Han et al. (2009)
ECB Survey on the access to Finance of SMES (SAFE)

Bespoke panel sample of SMEs in North Jutland, Denmark

ECB Survey on the access to Finance of SMES (SAFE)

US Federal Reserve Board's Survey of Small Business Finances (SSBF)

Bespoke Survey in Hanan and Guangdong province, China

US Federal Reserve Board's Survey of Small Business Finances (SSBF)

UK SME Business Barometer Surveys

UK biennial survey by the Federation of Small Businesses

US Survey of Small Business Finances 'the process is too difficult or don't want to incur debt' (p. 5-6)

'they would be turned down, that it was not the right time to borrow, or that banks were not lending' (p.398)

'if it does not apply for a loan for different reasons, such as tough loan prices or loan contract procedures or fear of rationing, that is, the scale of discouragement as a function of bank screening errors, application costs, and the difference in interest rates between the bank and other money lenders' (p. 35)

'did not apply due to anticipated rejection' ( $\mathrm{p}$. 122)

'During the last three years, were there times when the firm needed credit, but did not apply because it thought the application would be turned down' (p. 21)

'Have you decided not to apply for a loan anticipating a bank rejection' (p. 529)

'is a firm that did not apply for a loan during the previous 3 years because the firm feared rejection, even though it needed credit' (p. 47)

'demand for but not applying for any finance either because the firm feared rejection or the owner thought the finance was too expensive' (p. 1054)

'With respect to banks' loans (either new or renewal): did you apply for them over the past 6 months, or not? 1. Applied. 2: No, because of possible rejection' (p. 49)

'Did expectations of rejection make you abstain from applying for external finance for either development activities or working capital during the past year' (p.14)

'as firms with a need for a loan who nevertheless choose to not apply for a bank loan because (1) the loan procedure was too complicated; (2) interest rates were too high; (3) collateral requirement were too high; and (4) there was corruption in allocation' (p. 67)

'in the past two years has the fear of rejection stopped you from seeking a bank loan for your business' (p. 407)

'all businesses (both high and low risk) with capital demands, but which did not apply because of fear of rejection' (p.416)

This table outlines the technical definitions used within a selection of empirical studies examining discouraged borrowers, which have been published since 2009. This variation hinges on the different definitional issues utilised within surveys that have investigated borrower discouragement 
in time and human resources (Rostamkalaei et al., 2018) inhibiting SMEs from applying for finance given the opportunity cost and hassle of applying (Chakravarty and Xiang 2013; Rostamkalaei et al., 2018). ${ }^{5}$

While the issue of cost of finance is broadly consistent with the original concept of borrower discouragement proposed by Kon and Storey (2003), this issue of credit restrictions based on the price of finance are clearly pushing the boundaries of the original concept. Given this, it can be difficult to distinguish between SMEs who do and do not need finance (Xiang et al., 2015). Moreover, in some studies, factors behind borrower discouragement hinge upon issues such as collateral requirements and corruption (Chakravarty and Xiang 2013). Clearly, the concept of discouragement appears to be used inconsistently throughout the literature. This may account for discrepancies in estimates of borrower discouragement presented in the literature. This suggests that considerable caution should be exercised when comparing the empirical findings across studies of borrower discouragement.

\subsection{Borrower discouragement and SME innovative activity}

To date, there is a paucity of evidence regarding the potential effects of innovation on the likelihood of credit self-rationing in SMEs. Yet product and process innovations are important strategies used by SMEs seeking to improve efficiency in production and/or increase revenues by stimulating demand for innovative products and services. Often access to external finance is a fundamental pre-requisite driving firm-level innovation (Kerr \& Nanda, 2015; Lipczynski et al., 2017). Given the risk and uncertainty of outcome associated with entrepreneurial endeavours and innovative activity (Mazzucato, 2013), innovators are more likely to encounter significant barriers accessing finance. This manifests itself in rejected funding applications (Freel, 2007; Lee et al., 2015), higher interest rates on bank loans (Rostamkalaei

\footnotetext{
5 The issue of cost and hassle of applying for finance is consistent with the original concept of borrower discouragement which contends that application costs can be "considered as financial, in-kind or psychic' (Kon \& Storey, 2003, p. 37).
}

\& Freel, 2016), onerous collateral requirement and covenants, which can all ultimately foster borrower discouragement.

The link between innovation and discouragement has been considered in some studies. For example, Rostamkalaei et al. (2018) utilise the SME Finance Monitor survey (2011-2015) to examine the underlying characteristics of two different types of non-applicants who needed financing but did not apply: informally turned down (when lenders verbally inform an SME owner that a loan application is likely be denied) and discouraged borrowers (when the SME thought that it would be turned down or it was not the right time to apply for borrowing). While innovation was not the focus of the study, the authors find that informal turndowns are more prevalent amongst innovators and that (product and process) innovative activity is not associated with borrower discouragement. Freel et al. (2012) also find no evidence to suggest that SMEs which perceive innovation as a business strength were more likely to be discouraged borrowers. $^{6}$

Innovation is traditionally modelled as a binary choice capturing whether a firm innovates or not. However, not all innovation can be classified the same (Beck et al., 2016). Indeed, innovation can take many forms and includes activities such as product, process, radical and incremental innovations (Lipczynski et al., 2017). In the present study, we posit that the type, nature and scope of innovation is likely to have a material impact on borrower discouragement, given variations in the risk and uncertainty associated with different forms of innovation (Teece et al., 2016). There is no certainty that process innovation will lead to lowering the average cost function of a firm nor that a radical innovation (which implies advancements in knowledge due to the development of new products and processes that are new to the market) will gain traction in the market. However, radical

\footnotetext{
${ }^{6}$ It is worth noting that Freel et al. (2012) adopt a behavioural approach to quantify how SME owners perceive innovation (measured as a combination of $\mathrm{R} \& \mathrm{D}$ innovation, specialised expertise or products and flair, design and creativity) as a business strength and find no evidence of a significant effect of perceived innovation on discouragement. The approach adopted in the present study deviates significantly from this in that we examine the impact of (product, process, incremental and radical) innovation activities on the likelihood of borrower discouragement.
} 
innovation is likely to be characterised by higher levels of unknown unknowns due to both 'high technical and market uncertainty' than incremental innovations which merely entails modifications to existing products and processes (O'Connor \& Rice, 2013, p. 3).

Overall, prior evidence suggests that a multitude of factors are likely to determine the incidence of borrower discouragement. However, the role of innovation for the most part has been overlooked. This is surprising given the growing literature investigating the financing constraints facing innovative firms (Hall \& Lerner, 2010; Lee et al., 2015). The paucity of evidence regarding whether borrower discouragement is affected by innovation is clearly a compelling issue for further investigation for academics and policymakers alike and hence the focus of the present study.

\section{Data, definitions and methodology}

\subsection{Data}

For the purposes of our empirical analysis, we utilise the UK Longitudinal Small Business Survey (LSBS) which is a detailed nationally representative survey of the UK SMEs. The LSBS is a telephonebased survey of the UK small business owners and managers administered by BEIS. The survey is constructed using a stratified sample of owner-managers of SMEs with less than 250 employees across the four constituent parts of the UK (England, Northern Ireland, Scotland and Wales). The data available for use in the present study comprises SMEs that were interviewed during the period 2015-2018. The survey collects detailed information relating the financial and non-financial activities of SMEs, including: the nature of any innovative activities, attitudes toward accessing external finance and reasons for borrower discouragement.

\subsection{Identifying innovative SMEs}

Firm-level innovation can be defined in various ways. Product innovation involves the introduction of a new product, while process innovation normally involves the introduction of a cost-saving technologies. The distinction between product and process innovation is not always clear cut, however. New products often require new methods of production, while new production processes often alter the characteristics of the final product (Lipczynski et al., 2017). Innovation is also differentiated by the degree of novelty (Beck et al., 2016). Radical innovations represent significant advances or new forms of knowledge occurring primarily through the creation of new products and processes. Incremental innovations on the other hand involve the continuous improvement to existing products, processes or services that are new to the firm (Beck et al., 2016). While incremental innovation can lead to competitive advantages for SMEs by increasing efficiency, radical innovation can lead to substantial improvements to growth and returns (Love et al., 2016; Saridakis et al., 2019). Given the inherent lack of resources required to undertake radical innovation, incremental innovation is often the most common form of innovation for SMEs.

In the present study, we measure innovation as the introduction of new products (goods and services) and processes. Table 2 presents the definitions and specific LSBS survey questions used in the present study. Product innovation is proxied by firms that introduced any new or significantly improved goods (this excludes the resale of goods purchased from other businesses or changes of a solely aesthetic nature) and/or services innovations in the last 3 years. These firms represent $28 \%$ of our sample as shown in Table 3. Process innovation is proxied by the following survey question: 'Has your [business] introduced any new or significantly improved processes for producing or supplying goods or services in the last three years?' We observe in Table 3 that $15.9 \%$ of SMEs in our sample has introduced process innovation in the last 3 years.

Using the classification above, we classify innovative SMEs into three mutually exclusive groups comprising pure product innovators (17.6\% of SMEs), pure process innovators (5.5\% of SMEs) and SMEs that produce product and process innovations simultaneously $(10.3 \%)$. The detailed nature of the data enables us to distinguish between radical and incremental innovators (Beck et al., 2016; Saridakis et al., 2019). The responses to the survey question, 'Were any of these new or significantly improved goods and services innovations new to the market, or were they all just new to your [business]?', allow us to create a categorical variable that classifies product innovation as radical (new to the market) or incremental (new to the business). A similar approach is used to 
Table 2 Variable definition

\begin{tabular}{|c|c|c|}
\hline Variable & Definition & LSBS code \\
\hline \multicolumn{3}{|l|}{ Discouraged borrower } \\
\hline $\begin{array}{l}\text { Discouraged SME (conditional on } \\
\text { needing finance) }\end{array}$ & $\begin{array}{l}\text { SME had a need for finance in the last } 12 \\
\text { months but did not apply }\end{array}$ & $\mathrm{H} 95 / \mathrm{H} 4$ \\
\hline \multicolumn{3}{|l|}{ Innovation } \\
\hline Product innovation & $\begin{array}{l}\text { Introduction of new or significantly improved } \\
\text { goods and/or services in the last } 3 \text { years }\end{array}$ & J1SUM (2015-2017), J1 (2018) \\
\hline Process innovation & $\begin{array}{l}\text { Business introduced any new or signifi- } \\
\text { cantly improved processes for producing } \\
\text { or supplying goods or services in the last } \\
3 \text { years }\end{array}$ & $\mathrm{J} 3$ \\
\hline \multicolumn{3}{|l|}{ Innovation types } \\
\hline No innovation (base category) & $\begin{array}{l}\text { Firm has not been an innovator in the last } \\
3 \text { years }\end{array}$ & \\
\hline Pure product innovation & $\begin{array}{l}\text { Business introduced any new or signifi- } \\
\text { cantly improved goods and/or services in } \\
\text { the last } 3 \text { years }\end{array}$ & $\begin{array}{l}\text { Own elaboration based on J1SUM, J1 } \\
\text { and } \mathrm{J} 3\end{array}$ \\
\hline Pure process innovation & $\begin{array}{l}\text { Business introduced any new or signifi- } \\
\text { cantly improved processes for producing } \\
\text { or supplying goods or services in the last } \\
3 \text { years }\end{array}$ & $\begin{array}{l}\text { Own elaboration based on J1SUM, J1 } \\
\text { and J3 }\end{array}$ \\
\hline Product and process innovation & $\begin{array}{l}\text { Introduction of product and process innova- } \\
\text { tion }\end{array}$ & $\begin{array}{l}\text { Own elaboration based on J1SUM, J1 } \\
\text { and } \mathrm{J} 3\end{array}$ \\
\hline \multicolumn{3}{|l|}{ Novelty of product innovation } \\
\hline No product innovation (base category) & $\begin{array}{l}\text { Business has not introduced any product } \\
\text { innovation in the last } 3 \text { years }\end{array}$ & \\
\hline At least some new to the market & $\begin{array}{l}\text { If introduced any new or significantly } \\
\text { improved goods or services innovations } \\
\text { in the last } 3 \text { years: they were at least some } \\
\text { new to the market }\end{array}$ & $\mathrm{J} 2$ \\
\hline All just new to the business & $\begin{array}{l}\text { If introduced any new or significantly improved } \\
\text { goods or services innovations in the last } 3 \\
\text { years: they were all just new to the business }\end{array}$ & $\mathrm{J} 2$ \\
\hline \multicolumn{3}{|l|}{ Novelty of process innovation } \\
\hline No process innovation (base category) & $\begin{array}{l}\text { Business has not introduced any process } \\
\text { innovation in the last } 3 \text { years }\end{array}$ & \\
\hline At least some new to the industry & $\begin{array}{l}\text { If introduced any improved processes for } \\
\text { producing or supplying goods or services } \\
\text { in the last } 3 \text { years: they were at least some } \\
\text { new to the industry }\end{array}$ & $\mathrm{J} 4$ \\
\hline All just new to the business & $\begin{array}{l}\text { If introduced any improved processes for produc- } \\
\text { ing or supplying goods or services in the last } 3 \\
\text { years: they were all just new to the business }\end{array}$ & $\mathrm{J} 4$ \\
\hline \multicolumn{3}{|l|}{ Control variables } \\
\hline Aims to grow & Aim to grow sales over the next 3 years & $\mathrm{R} 1$ \\
\hline Size & & A2SPSS 1 \\
\hline Zero employees (base category) & $\begin{array}{l}\text { Zero employee business had no employees } \\
\text { on their payroll (excluding owners and } \\
\text { partners) at the time of the interview }\end{array}$ & \\
\hline Micro & 1-9 employees & \\
\hline Small & 10-49 employees & \\
\hline Medium & 50-249 employees & \\
\hline
\end{tabular}


Table 2 (continued)

\begin{tabular}{|c|c|c|}
\hline Variable & Definition & LSBS code \\
\hline Business age & Age of the firm & $\begin{array}{l}\text { A6SUM and A6, missing values for } 2016 \\
\text { are completed with values from } 2015\end{array}$ \\
\hline \multicolumn{3}{|l|}{$0-5$ years (base category) } \\
\hline \multicolumn{3}{|l|}{$6-10$ years } \\
\hline \multicolumn{3}{|l|}{$11-20$ years } \\
\hline \multicolumn{3}{|l|}{$20+$ years } \\
\hline Turnover change & $\begin{array}{l}\text { Turnover in the past } 12 \text { months, compared } \\
\text { with the previous } 12 \text { months }\end{array}$ & $\mathrm{P} 2$ \\
\hline \multicolumn{3}{|l|}{ Decreased (base category) } \\
\hline \multicolumn{3}{|l|}{ Stayed roughly the same } \\
\hline \multicolumn{3}{|l|}{ Increased } \\
\hline Profit & $\begin{array}{l}\text { Firm generate a profit or surplus after tak- } \\
\text { ing into account all sources of income in } \\
\text { the last financial year }\end{array}$ & $\mathrm{P} 12$ \\
\hline Urban area & $\begin{array}{l}\text { Broad urban/rural categorisation from } \\
\text { postcode }\end{array}$ & URBRUR2 \\
\hline Female led & Business is women-led & WLED \\
\hline Minority Ethnic Led & Business is MEG-led & MLED \\
\hline Family owned & $\begin{array}{l}\text { Business a family-owned business (i.e. one } \\
\text { which is majority owned by members of } \\
\text { the same family) }\end{array}$ & A12 \\
\hline Business plan & Business has a formal written business plan & F5 \\
\hline Legal status & Legal for of the firm & A5SUM \\
\hline \multicolumn{3}{|l|}{ Other (base category) } \\
\hline \multicolumn{3}{|l|}{ Sole proprietorship } \\
\hline Company & $\begin{array}{l}\text { It includes any of the following catego- } \\
\text { ries: 'Private limited company, limited } \\
\text { by shares (LTD.); Public Ltd Company } \\
\text { (PLC); Private company limited by } \\
\text { guarantee; Community Interest Company } \\
\text { (CIC, limited by guarantee or shares); } \\
\text { Private Unlimited Company; Foreign } \\
\text { Company.' }\end{array}$ & \\
\hline \multicolumn{3}{|l|}{ Partnership } \\
\hline Region & Region where the firm has its headquarters & NATION \\
\hline \multicolumn{3}{|l|}{ England (base category) } \\
\hline \multicolumn{3}{|l|}{ Scotland } \\
\hline \multicolumn{3}{|l|}{ Wales } \\
\hline \multicolumn{3}{|l|}{ Northern Ireland } \\
\hline Sector & Industry Sector & SECTOR \\
\hline Manufacturing sector (base category) & $\begin{array}{l}\text { Production and construction (SIC 2007: } \\
\text { ABCDEF) }\end{array}$ & \\
\hline Transportation and retail services & $\begin{array}{l}\text { Transport, retail and food service/ accom- } \\
\text { modation (SIC 2007: GHI) }\end{array}$ & \\
\hline Business services & Business services (SIC 2007: JKLMN) & \\
\hline Other services & Other services (SIC 2007: PQRS) & \\
\hline
\end{tabular}

This Table shows variable names and definitions of our dependent and explanatory variables. All variables were gathered from the Longitudinal Small Business Survey, 2015-2018 
capture radical and incremental process innovations, based on responses to the following question: 'Were any of these new or significantly improved processes new to your industry, or were they all just new to your [business]?'

The data reported in Table 3 suggests that around $8.8 \%$ of SMEs in our sample have introduced a radical product innovation in the last 3 years. We also find that $18.9 \%$ of SMEs introduced incremental product innovations. The percentage of SMEs undertaking radical and incremental process innovations is generally lower than for product innovation accounting for $3.8 \%$ and $11.9 \%$, respectively.

\subsection{Identifying discouraged SMEs}

The holistic definition of borrower discouragement used in the present study is whether SMEs had a need for finance in the last 12 months, but did not apply because one of the following main reasons: fear of rejection, cost of credit, additional risk-taking,

Table 3 Summary statistics

\begin{tabular}{|c|c|c|c|}
\hline & Mean & Std. Dev. & $N$ \\
\hline \multicolumn{4}{|l|}{ Discouraged borrower } \\
\hline No need finance (all sample) & 0.844 & 0.363 & 44,453 \\
\hline Need finance-applicant (all sample) & 0.075 & 0.263 & 44,453 \\
\hline Need finance—discouraged (all sample) & 0.082 & 0.274 & 44,453 \\
\hline Discouraged SME (conditional on needing finance) & 0.523 & 0.500 & 9,781 \\
\hline \multicolumn{4}{|l|}{ Innovation } \\
\hline \multicolumn{4}{|l|}{ Innovation type } \\
\hline Product innovator & 0.280 & 0.449 & 46,030 \\
\hline Process innovator & 0.159 & 0.366 & 45,790 \\
\hline \multicolumn{4}{|l|}{ Innovation strategy } \\
\hline Non-innovator & 0.666 & 0.472 & 46,173 \\
\hline Product innovator (pure) & 0.176 & 0.381 & 46,173 \\
\hline Process innovator (pure) & 0.055 & 0.228 & 46,173 \\
\hline Innovator (product and process) & 0.103 & 0.305 & 46,173 \\
\hline \multicolumn{4}{|l|}{ Novelty of product innovation } \\
\hline Non-product innovator (base category) & 0.723 & 0.447 & 45,784 \\
\hline At least some new to the market (radical) & 0.088 & 0.283 & 45,784 \\
\hline All just new to the business (incremental) & 0.189 & 0.391 & 45,784 \\
\hline \multicolumn{4}{|l|}{ Novelty of process innovation } \\
\hline Non-process innovator (base category) & 0.842 & 0.364 & 45,618 \\
\hline At least some new to the industry (radical) & 0.038 & 0.192 & 45,618 \\
\hline All just new to the business (incremental) & 0.119 & 0.324 & 45,618 \\
\hline \multicolumn{4}{|l|}{ Control variables } \\
\hline \multicolumn{4}{|l|}{ Entrepreneur orientation } \\
\hline Aims to grow & 0.519 & 0.500 & 46,335 \\
\hline \multicolumn{4}{|l|}{ Size } \\
\hline Zero employees (base category) & 0.758 & 0.428 & 46,335 \\
\hline Micro (1-9) & 0.199 & 0.399 & 46,335 \\
\hline Small (10-49) & 0.037 & 0.189 & 46,335 \\
\hline Medium (50-249) & 0.006 & 0.078 & 46,335 \\
\hline \multicolumn{4}{|l|}{ Business age } \\
\hline $0-5$ years (base category) & 0.172 & 0.378 & 46,171 \\
\hline $6-10$ years & 0.185 & 0.388 & 46,171 \\
\hline $11-20$ years & 0.252 & 0.434 & 46,171 \\
\hline $20+$ years & 0.391 & 0.488 & 46,171 \\
\hline
\end{tabular}


Table 3 (continued)

\begin{tabular}{|c|c|c|c|}
\hline & Mean & Std. Dev. & $N$ \\
\hline \multicolumn{4}{|l|}{ Turnover change } \\
\hline Decreased (base category) & 0.221 & 0.415 & 43,978 \\
\hline Stayed the same & 0.491 & 0.500 & 43,978 \\
\hline Increased & 0.288 & 0.453 & 43,978 \\
\hline \multicolumn{4}{|l|}{ Profitability } \\
\hline Profit & 0.808 & 0.394 & 43,330 \\
\hline \multicolumn{4}{|l|}{ Business characteristics } \\
\hline Urban area & 0.705 & 0.456 & 46,267 \\
\hline Female led & 0.211 & 0.408 & 42,093 \\
\hline Minority ethnic led & 0.052 & 0.222 & 41,142 \\
\hline Family owned & 0.867 & 0.340 & 45,963 \\
\hline Business plan & 0.289 & 0.453 & 44,992 \\
\hline \multicolumn{4}{|l|}{ Legal status } \\
\hline Other (base category) & 0.028 & 0.166 & 46,335 \\
\hline Sole proprietorship & 0.469 & 0.499 & 46,335 \\
\hline Company & 0.433 & 0.496 & 46,335 \\
\hline Partnership & 0.070 & 0.255 & 46,335 \\
\hline \multicolumn{4}{|l|}{ Region } \\
\hline England (base category) & 0.879 & 0.326 & 46,335 \\
\hline Scotland & 0.060 & 0.238 & 46,335 \\
\hline Wales & 0.038 & 0.190 & 46,335 \\
\hline Northern Ireland & 0.023 & 0.149 & 46,335 \\
\hline \multicolumn{4}{|l|}{ Sector } \\
\hline Manufacturing sector (base category) & 0.260 & 0.439 & 46,335 \\
\hline Transportation and retail services & 0.187 & 0.390 & 46,335 \\
\hline Business services & 0.329 & 0.470 & 46,335 \\
\hline Other services & 0.224 & 0.417 & 46,335 \\
\hline
\end{tabular}

This table reports the summary statistics using data from the Longitudinal Small Business Survey, 2015-2018. Cross-sectional survey weights applied to represent the population of SMEs in the UK. Respondents who answer 'I don't know' or refused to answer are not included in the analyses. Variable definitions are reported in Table 2

poor credit history, prevailing economic conditions, knowledge of financial sources and the time and hassle associated with applying (See Figure A1 in the appendix). Table 3 reveals that $8.2 \%$ of all SMEs surveyed are discouraged borrowers. Overall, $52.3 \%$ of SMEs are considered discouraged SMEs (conditional on needing finance).

Table A1 and Figure A2 in the Appendix provide further descriptive statistics on the sample composition of discouraged borrowers (conditional on needing finance). Our results suggest that $64.2 \%$ of discouraged SMEs in our sample made profits in the previous financial year. We also observe that the turnover increased or remained roughly similar to the previous 12 months for $70.7 \%$ of the discouraged SMEs in our sample (See Table A1). Figures relating to expectations regarding future turnover (See Figure A2) suggest that $89.1 \%$ of discouraged SMEs expect turnover to increase or stay the same in the next 12 months. Overall, these descriptive statistics provide evidence that the sample of discouraged is characterised by borrowers of a relatively good economic profile. Consequently, borrower 
discouragement can be seen as a potentially inefficient self-rationing mechanism. ${ }^{7}$

Figures A3 and A4 in the Appendix present the distribution of the sample of discouraged borrowers and innovative SMES across industry sectors. Discouraged borrowers are largely present across all industry sectors with a relatively higher proportion in the construction sector $(\mathrm{F})$. Innovative firms are in a similar way present across all industry sectors with a higher proportion in the professional/scientific sector (M). ${ }^{8}$

\subsection{Control variables}

We control for several variables that are likely to affect borrower discouragement. These include growth intentions, size, firm age, change in turnover, profitability, location, gender, ethnicity, family ownership, legal structure, region and industry sector. Growth-oriented SMEs are more likely to require external funding and thus more likely to be discouraged borrowers. These SMEs represent $51.8 \%$ of our sample. SME size is measured by total employment according to one of four size categories: 0 employees (75.8\% of SMEs), 1-9 employees (19.9\% of SMEs), 10-49 employees (3.7\% of SMEs) and 50-249 employees ( $0.6 \%$ of SMEs). Our sample of SMEs is predominantly mature $(20+$ years old, $39.1 \%)$ and located in urban areas $(70.5 \%)$. Profitability is measured using an indicator variable that captures whether a SME made a profit in the last financial year $(80.8 \%$ of SMEs). Turnover (sales revenue) remained constant or increased in around $80 \%$ of the sample.

We also control for cases where the owner is either a female $(21.1 \%)$, ethnic minority group $(5.2 \%)$ or the SME is family owned (86.7\%). We also differentiate between proprietorships, partnerships and companies in order to control for differences in legal form. Companies and sole proprietorship constitute around $43 \%$ and $47 \%$ of our sample, respectively. The majority of SMEs are located in England (87.9\%) and are distributed across all of the main industry sectors.

\footnotetext{
7 The lack of additional proxies regarding the availability of profitable investment projects for SMEs or other metrics to identify credit worthy SMEs is a limitation of the LSBS Survey and our empirical analysis.

${ }^{8}$ We are thankful to an anonymous referee for drawing attention to this issue.
}

\subsection{Methodology}

One important feature of defining borrower discouragement is that these firms require external finance, but do not apply for it. This is crucial as innovative firms are more likely to seek external finance (Lee et al., 2015). Since borrower discouragement is only observed for those SMEs, which have a need for finance, estimating both events independently could lead to sample selection problems. The problem is that the unobserved variables that determine the need for finance may be correlated with the likelihood of being a discouraged borrower and so lead to biased coefficient estimates. Given the binary nature of the dependent variable, we address this bias by using a probit model with sample selection (Van de Ven \& Van Praag, 1981).

This model assumes that there is an underlying relationship (latent equation) $y_{j}^{*}=X_{j} \beta+\mu_{1 j}$ such that we observe only the binary outcome (outcome equation: discouraged borrower) $\mathrm{y}_{\mathrm{j}}^{\text {probit }}=\left(y_{\mathrm{j}}^{*}>0\right)$. The dependent variable, however, is not always observed. Rather, the dependent variable for observation $j$ is observed if (selection equation: SME needs finance) $\mathrm{y}_{\mathrm{j}}^{\text {select }}=\left(\mathrm{Z}_{\mathrm{j}} \gamma+\mu_{2 \mathrm{j}}>0\right) \quad$ where $\quad \mu_{1} \sim \mathrm{N}(0,1)$; $\mu_{2} \sim \mathrm{N}(0,1) ; \operatorname{corr}\left(\mu_{1}, \mu_{2}\right)=\rho$ (rho). When $\rho=0$, there is no evidence of selection bias; the outcome and selection equations are independent, making estimation of the selection model unnecessary.

However, since the model is estimated by maximum likelihood (ML), $\rho$ is not directly estimated. Instead, the Heckprobit routine directly estimates a nonlinear transformation of $\rho$ (athrho) defined as athrho $=\frac{1}{2} \ln \left(\frac{1+\rho}{1-\rho}\right)$. A significant athrho implies that $\rho \neq 0$ and indicates the presence of selection bias in the model. A Wald test is reported in all tables; it compares the log likelihood of the full model with sample selection with the sum of the log likelihoods of running simple probits for each equation. If the test is significant, there is statistical difference between both models, suggesting that selection bias is present and providing further support that $\rho \neq 0$.

All our estimated models include lagged independent variables and dummy variables to account for the legal status, region, sector of the SME and year of survey. All results are reported in terms of average marginal effects of the explanatory variables on the probabilities of needing finance (selection equation) 
and on the probability of being discouraged conditional on selection (i.e. need finance). The average marginal effects indicate the change in probability when the independent variable switches from the reference category to the category in question. All models are estimated via maximum-likelihood, and standard errors are clustered at the firm level to account for potential correlation of errors within clusters.

\section{Results}

Table 4 present results for the impact of product innovation on borrower discouragement. Models 1 and 2 successively but separately introduce additional control variables in addition of fixed effects (legal, region, sector and survey year) which are present in all models. The exclusion restriction used in the selection equation in model 1 is legal status dummy, model 2 includes both business plan and legal status, while only a business plan dummy is used in model 3 along with the full set of control variables.

In line with previous studies, we find that innovation (either product or process) is positively related to the need for finance in the selection equation. We do not comment further on these results given the consistency across all estimated models. For the outcome equation (i.e. the probability of being a discouraged borrower conditional on requiring finance), we find that product innovation has a positive influence on borrower discouragement. More precisely, the results of estimating model 1 suggest that being product innovator increases the likelihood of borrower discouragement by 12.6 percentage points compared to a non-product innovative counterpart. However, the magnitude of the marginal effect decreases to $6.5-5.5 \%$ but remains positive and statistically significant after including additional control variables in models 2 and 3, respectively. Results for SMEs introducing process innovations are presented in Table 5. According to the results, process innovation is also positively associated with borrower discouragement, but the magnitude of this effect is approximately half of that obtained for product innovation and merely marginally significant in model 3 . This is in line with prior research demonstrating that cutting-edge R\&D investments are more likely to face difficulties in obtaining credit whereas those of a more prosaic and routine nature such as process innovations do not encounter such credit obstacles due to lower informational asymmetries (Czarnitzki \& Hottenrott, 2011).

A potential issue regarding the definition of innovation in Tables 4 and 5 is that the reference category for product (process) innovators includes both noninnovators and process (product) innovators bundled in one group. To disentangle the effect of innovation, we classify SMEs into three mutually exclusive comprising: pure product innovation, pure process innovation and product and process innovation. The reference category are exclusively non-innovator SMEs. This approach allows us to make a clear comparison with respect to the group of non-innovators. The results reported in Table 6 suggest that SMEs introducing pure product and both product and process innovations simultaneously are more likely to be discouraged borrowers compared to their non-innovative counterparts (by $6.2 \%$ and $8.5 \%$, respectively) based on model 3. In this model, pure process innovation coefficient loses statistical significance. The marginal effect of engaging in both product and process innovation on borrower discouragement is around two percentage points higher with respect to pure product innovators. Overall, the results suggest that relative to other forms of innovation, engaging in a combination of product and process innovation has a stronger impact on borrower discouragement.

In Table 7, we examine the association between the novelty of product innovation and the incidence of borrower discouragement. The results suggest that introducing either radical or incremental product innovation increases the SME's propensity of being discouraged by $6.6 \%$ and $5 \%$, respectively (model 3 ) compared to SMEs that did not introduce product innovations. However, our results for novelty of process innovations in Table 8 suggest, in line with our previous results, that either radical or incremental process innovation is not influencing borrower discouragement. ${ }^{9}$

\footnotetext{
9 Our baseline results remain largely unchanged after controlling by SME's seeking external advice or information (as a proxy for education level of entrepreneurs), switching banks, using the perceived market competition as an obstacle for doing busines as an additional exclusion restriction and employing a standard probit model using the full sample without sample selection. A summary of the estimation results is reported in Table A2 in the Appendix. We are thankful to an anonymous referee for suggesting these additional robustness tests.
} 
Table 4 Heckman probit results. The impact of product innovation on being a discouraged borrower

\begin{tabular}{|c|c|c|c|c|c|c|}
\hline & \multicolumn{2}{|l|}{ Model 1} & \multicolumn{2}{|l|}{ Model 2} & \multicolumn{2}{|l|}{ Model 3} \\
\hline & Selection & Outcome & Selection & Outcome & Selection & Outcome \\
\hline Innovative firm ${ }_{\mathrm{t}-1}$ & $\begin{array}{l}0.064 * * * \\
(9.23)\end{array}$ & & $\begin{array}{l}0.040 * * * \\
(5.04)\end{array}$ & & $\begin{array}{l}0.040 * * * \\
(5.13)\end{array}$ & \\
\hline Product innovator $_{\mathrm{t}-1}$ & & $\begin{array}{l}0.126 * * * \\
(4.38)\end{array}$ & & $\begin{array}{l}0.065 * * * \\
(2.82)\end{array}$ & & $\begin{array}{l}0.055 * * \\
(2.46)\end{array}$ \\
\hline Aims to grow $_{t-1}$ & & & $\begin{array}{l}0.085 * * * \\
(10.06)\end{array}$ & $\begin{array}{l}-0.009 \\
(-0.33)\end{array}$ & $\begin{array}{l}0.086 * * * \\
(10.09)\end{array}$ & $\begin{array}{l}-0.006 \\
(-0.22)\end{array}$ \\
\hline Size $_{\mathrm{t}-1}:$ Micro & & & $\begin{array}{l}0.037 * * * \\
(3.63)\end{array}$ & $\begin{array}{l}-0.029 \\
(-0.94)\end{array}$ & $\begin{array}{l}0.039 * * * \\
(3.81)\end{array}$ & $\begin{array}{l}-0.012 \\
(-0.39)\end{array}$ \\
\hline Size $_{\mathrm{t}-1}:$ Small & & & $\begin{array}{l}0.075 * * * \\
(5.93)\end{array}$ & $\begin{array}{l}-0.134 * * * \\
(-4.14)\end{array}$ & $\begin{array}{l}0.078 * * * \\
(6.16)\end{array}$ & $\begin{array}{l}-0.110 * * * \\
(-3.32)\end{array}$ \\
\hline Size $_{\mathrm{t}-1}:$ Medium & & & $\begin{array}{l}0.091 * * * \\
(5.80)\end{array}$ & $\begin{array}{l}-0.226 * * * \\
(-6.47)\end{array}$ & $\begin{array}{l}0.094 * * * \\
(5.97)\end{array}$ & $\begin{array}{l}-0.201 * * * \\
(-5.49)\end{array}$ \\
\hline Business age $_{\mathrm{t}-1}: 6-10$ years & & & $\begin{array}{l}0.007 \\
(0.43)\end{array}$ & $\begin{array}{l}0.022 \\
(0.53)\end{array}$ & $\begin{array}{l}0.006 \\
(0.39)\end{array}$ & $\begin{array}{l}0.021 \\
(0.50)\end{array}$ \\
\hline Business age $_{\mathrm{t}-1}: 11-20$ years & & & $\begin{array}{l}-0.013 \\
(-0.84)\end{array}$ & $\begin{array}{l}0.039 \\
(0.97)\end{array}$ & $\begin{array}{l}-0.014 \\
(-0.87)\end{array}$ & $\begin{array}{l}0.036 \\
(0.91)\end{array}$ \\
\hline Business age $_{\mathrm{t}-1}: 20+$ years & & & $\begin{array}{l}-0.016 \\
(-1.13)\end{array}$ & $\begin{array}{l}-0.013 \\
(-0.36)\end{array}$ & $\begin{array}{l}-0.017 \\
(-1.17)\end{array}$ & $\begin{array}{l}-0.018 \\
(-0.47)\end{array}$ \\
\hline Turnover change (stayed the same) ${ }_{t-1}$ & & & $\begin{array}{l}-0.035^{* * *} \\
(-3.34)\end{array}$ & $\begin{array}{l}-0.082 * * * \\
(-3.08)\end{array}$ & $\begin{array}{l}-0.035^{* * *} \\
(-3.35)\end{array}$ & $\begin{array}{l}-0.082 * * * \\
(-3.09)\end{array}$ \\
\hline Turnover change (increased) ${ }_{t-1}$ & & & $\begin{array}{l}-0.004 \\
(-0.36)\end{array}$ & $\begin{array}{l}-0.131 * * * \\
(-4.71)\end{array}$ & $\begin{array}{l}-0.004 \\
(-0.36)\end{array}$ & $\begin{array}{l}-0.130 * * * \\
(-4.73)\end{array}$ \\
\hline Profit $_{t-1}$ & & & $\begin{array}{l}-0.138 * * * \\
(-10.69)\end{array}$ & $\begin{array}{l}-0.150 * * * \\
(-6.01)\end{array}$ & $\begin{array}{l}-0.138 * * * \\
(-10.68)\end{array}$ & $\begin{array}{l}-0.151 * * * \\
(-6.01)\end{array}$ \\
\hline Location $_{\mathrm{t}}:$ Urban area & & & $\begin{array}{l}-0.011 \\
(-1.16)\end{array}$ & $\begin{array}{l}-0.022 \\
(-0.95)\end{array}$ & $\begin{array}{l}-0.011 \\
(-1.17)\end{array}$ & $\begin{array}{l}-0.021 \\
(-0.93)\end{array}$ \\
\hline Female led ${ }_{t-1}$ & & & $\begin{array}{l}0.004 \\
(0.34)\end{array}$ & $\begin{array}{l}0.006 \\
(0.23)\end{array}$ & $\begin{array}{l}0.003 \\
(0.29)\end{array}$ & $\begin{array}{l}0.002 \\
(0.07)\end{array}$ \\
\hline Minority Ethnic Led ${ }_{t-1}$ & & & $\begin{array}{l}0.086 * * * \\
(3.83)\end{array}$ & $\begin{array}{l}0.131 * * * \\
(2.97)\end{array}$ & $\begin{array}{l}0.086^{* * * *} \\
(3.83)\end{array}$ & $\begin{array}{l}0.133 * * * \\
(3.01)\end{array}$ \\
\hline Family owned ${ }_{t-1}$ & & & $\begin{array}{l}0.016 \\
(1.64)\end{array}$ & $\begin{array}{l}0.027 \\
(1.07)\end{array}$ & $\begin{array}{l}0.016 \\
(1.61)\end{array}$ & $\begin{array}{l}0.023 \\
(0.93)\end{array}$ \\
\hline Business plan $_{\mathrm{t}-1}$ & & & $\begin{array}{l}0.033 * * * \\
(4.11)\end{array}$ & & $\begin{array}{l}0.033 * * * \\
(4.06)\end{array}$ & \\
\hline Fixed effects & & & & & & \\
\hline Legal status & Yes & No & Yes & No & Yes & Yes \\
\hline Region & Yes & Yes & Yes & Yes & Yes & Yes \\
\hline Sector & Yes & Yes & Yes & Yes & Yes & Yes \\
\hline Year & Yes & Yes & Yes & Yes & Yes & Yes \\
\hline Athrho & $\begin{array}{l}1.877 * * * \\
(3.19)\end{array}$ & & $\begin{array}{l}0.983 * * * \\
(2.78)\end{array}$ & & $\begin{array}{l}0.739 * * \\
(2.29)\end{array}$ & \\
\hline$\rho$ & 16022.000 & & 12976.000 & & 12976.000 & \\
\hline$N$ & 3296.000 & & 2688.000 & & 2688.000 & \\
\hline Selected & 12726.000 & & 10288.000 & & 10288.000 & \\
\hline
\end{tabular}


Table 4 (continued)

\begin{tabular}{|c|c|c|c|c|c|c|}
\hline & \multicolumn{2}{|l|}{ Model 1} & \multicolumn{2}{|l|}{ Model 2} & \multicolumn{2}{|l|}{ Model 3} \\
\hline & Selection & Outcome & Selection & Outcome & Selection & Outcome \\
\hline Nonselected & 0.954 & & 0.754 & & 0.628 & \\
\hline Log pseudolikelihood & -10183.246 & & -7907.691 & & -7904.761 & \\
\hline Wald test of indep. Eqns $(\rho=0)$ & 10.162 & & 7.712 & & 5.247 & \\
\hline Prob > chi 2 & 0.001 & & 0.005 & & 0.022 & \\
\hline
\end{tabular}

This table present the marginal effects from a Heckman probit model with sample selection (Van de Ven \& Van Praag, 1981) which is estimated using the Stata 'Heckprobit' routine (StataCorp, 2019). The selection equation relates to the probability of needing finance. The outcome equation relates to the probability of being a discouraged borrower conditional on needing finance. All regressions include a constant term. The exclusion restriction used in the selection equation is business plan and legal status dummy variables in models 1-2 and only business plan dummy in model 3. The excluded variables for control variables are zero employees (size), 0-5 years (business age), 18-30 years old (owner's age) and decreased (turnover change). Z-statistics adjusted for clustering at firm level are reported in parentheses. $* * * * *$ and $*$ Significant at the $1 \%, 5 \%$ and $10 \%$ levels, respectively

Turning to the control variables in Tables 4, 5, 6, 7 and 8 , we are able to observe which business-related characteristics are more likely to increase borrower discouragement. The results suggest that larger $(>10$ employees), profitable and growing SMEs (i.e. exhibiting an increased turnover) are less likely to be discouraged borrowers. Increased turnover and profitability tend to improve the cash position of SMEs and hence increase confidence that any application for external finance is likely to be accepted. We also find that SMEs led by entrepreneurs belonging to an ethnic minority are more likely to be discouraged borrowers. The marginal effect is economically and statistically significant across all models, in line with previous literature (Neville et al., 2018). These control variables affecting borrower discouragement remain significant across all estimations.

\subsection{Propensity score matching exercise}

If ex-ante innovators are more likely to be discouraged borrowers than non-innovators with comparable characteristics, the results of the empirical analysis could be affected. In order to explore this possibility and provide further evidence supporting our previous results, we follow Rosenbaum and Rubin (1983) and use propensity score matching (PSM) as a means of addressing such concerns. Matching restricts inference to the sample of innovators (the treatment group) and non-innovators (the control group). The treatment group is matched with the control group on the basis of a propensity score, which is a function of firm-level observable characteristics. Propensity scores are estimated via a logit model utilising a variety of SME characteristics (aims to grow, size, business age, turnover change, profits, urban location, women lead, minority ethnic lead, family owned, business plan, legal status, region, sector and year dummies) as independent variables. We match innovative SMEs with one, four and eight corresponding (nearest neighbour) non-innovative SMEs.

One of the assumptions required to use treatmenteffects estimators is the overlap assumption, which states that each individual has a positive probability of receiving each treatment. Figure A5 in the appendix displays the estimated density of the predicted probabilities that an untreated SME is assigned to treatment and the estimated density of the predicted probabilities that a treated SME is assigned to treatment. Consistent with the overlap assumption, the estimated density plots have considerable mass in the regions where they overlap, little mass around 0 , and little mass around 1 . Thus, there is no evidence that the overlap assumption is violated.

If models are well specified, they should also balance all covariates. For example, reviewing the covariate balance summary in Table A3 corresponding to the results reported in Table 9, panel A (1 match per observation) for innovators (product and/or process), we see that the weighted standardised differences are largely close to zero and the variance close to one, which suggests that our model balances all covariates. ${ }^{10}$ Table 9 presents the average treatment effect

\footnotetext{
10 The raw columns illustrate that differences are large prior to weighting. Covariate balance summaries for the remaining of models reported in Table 9 offer similar results and are available upon request. To further verify the quality of matching, Figure A6 in the Appendix shows the distribution of the propensity score for both groups before and after matching and suggests that the matches are appropriate.
} 
Table 5 Heckman probit results. The impact of process innovation on being a discouraged borrower

\begin{tabular}{|c|c|c|c|c|c|c|}
\hline & \multicolumn{2}{|l|}{ Model 1} & \multicolumn{2}{|l|}{ Model 2} & \multicolumn{2}{|l|}{ Model 3} \\
\hline & Selection & Outcome & Selection & Outcome & Selection & Outcome \\
\hline \multirow{2}{*}{$\begin{array}{l}\text { Innovative firm } \\
\text { (process/prod- } \\
\text { uct) }{ }_{\mathrm{t}-1}\end{array}$} & $0.060 * * *$ & & $0.038 * * *$ & & $0.039 * * *$ & \\
\hline & $(6.55)$ & & $(4.31)$ & & $(4.68)$ & \\
\hline \multirow[t]{2}{*}{ Process innovator ${ }_{\mathrm{t}-1}$} & & $0.046 * *$ & & $0.045^{*}$ & & $0.038^{*}$ \\
\hline & & $(2.00)$ & & $(1.91)$ & & $(1.66)$ \\
\hline \multirow[t]{2}{*}{ Aims to grow ${ }_{t-1}$} & & & $0.086 * * *$ & -0.006 & $0.086 * * *$ & -0.003 \\
\hline & & & (10.16) & $(-0.23)$ & (10.17) & $(-0.13)$ \\
\hline \multirow[t]{2}{*}{ Size $_{\mathrm{t}-1}:$ micro } & & & $0.037 * * *$ & -0.032 & $0.038 * * *$ & -0.014 \\
\hline & & & $(3.56)$ & $(-1.06)$ & (3.73) & $(-0.46)$ \\
\hline \multirow[t]{2}{*}{ Size $_{t-1}:$ small } & & & $0.075^{* * *}$ & $-0.138^{* * *}$ & $0.078 * * *$ & $-0.113 * * *$ \\
\hline & & & $(5.87)$ & $(-4.29)$ & $(6.14)$ & $(-3.38)$ \\
\hline \multirow[t]{2}{*}{ Size $_{t-1}:$ medium } & & & $0.091 * * *$ & $-0.230 * * *$ & $0.093 * * *$ & $-0.204 * * *$ \\
\hline & & & $(5.75)$ & $(-6.63)$ & $(5.93)$ & $(-5.57)$ \\
\hline \multirow{2}{*}{$\begin{array}{l}\text { Business age }_{t-1} \text { : } \\
\quad 6-10 \text { years }\end{array}$} & & & 0.006 & 0.023 & 0.006 & 0.022 \\
\hline & & & $(0.39)$ & $(0.57)$ & $(0.36)$ & $(0.53)$ \\
\hline \multirow{2}{*}{$\begin{array}{c}\text { Business age }_{t-1} \\
11-20 \text { years }\end{array}$} & & & -0.014 & 0.037 & -0.015 & 0.035 \\
\hline & & & $(-0.89)$ & $(0.93)$ & $(-0.92)$ & $(0.88)$ \\
\hline \multirow{2}{*}{$\begin{array}{c}\text { Business age }_{t-1}: \\
20+\text { years }\end{array}$} & & & -0.017 & -0.015 & -0.017 & -0.018 \\
\hline & & & $(-1.16)$ & $(-0.40)$ & $(-1.19)$ & $(-0.48)$ \\
\hline \multirow{3}{*}{$\begin{array}{l}\text { Turnover change } \\
\text { (stayed the same) } \\
\mathrm{t}-1\end{array}$} & & & $-0.035^{* * *}$ & $-0.081 * * *$ & $-0.035^{* * *}$ & $-0.081 * * *$ \\
\hline & & & & & & \\
\hline & & & $(-3.34)$ & $(-3.03)$ & $(-3.35)$ & $(-3.05)$ \\
\hline \multirow{2}{*}{$\begin{array}{l}\text { Turnover change } \\
\text { (increased) }{ }_{t-1}\end{array}$} & & & -0.004 & $-0.129 * * *$ & 0.004 & $-0.130 * * *$ \\
\hline & & & $(-0.33)$ & $(-4.67)$ & $(-0.34)$ & $(-4.72)$ \\
\hline Profit $_{t-1}$ & & & $\begin{array}{r}-0.138^{* * *} \\
(-10.67)\end{array}$ & $-0.152 * * *(-6.07)$ & $\begin{array}{r}-0.137 * * * \\
(-10.67)\end{array}$ & $-0.153 * * *(-6.07)$ \\
\hline \multirow{2}{*}{$\begin{array}{l}\text { Location }_{\mathrm{t}} \text { : urban } \\
\text { area }\end{array}$} & & & -0.011 & -0.021 & -0.011 & -0.022 \\
\hline & & & $(-1.21)$ & $(-0.92)$ & $(-1.22)$ & $(-0.94)$ \\
\hline \multirow[t]{2}{*}{ Female led ${ }_{t-1}$} & & & 0.003 & 0.003 & 0.002 & -0.002 \\
\hline & & & $(0.24)$ & $(0.10)$ & $(0.20)$ & $(-0.06)$ \\
\hline \multirow{2}{*}{$\begin{array}{l}\text { Minority ethnic } \\
\text { led }_{t-1}\end{array}$} & & & $0.085 * * *$ & $0.126 * * *$ & $0.085 * * *$ & $0.128 * * *$ \\
\hline & & & $(3.79)$ & $(2.84)$ & $(3.80)$ & $(2.89)$ \\
\hline \multirow[t]{2}{*}{ Family owned ${ }_{t-1}$} & & & 0.016 & 0.026 & 0.016 & 0.022 \\
\hline & & & $(1.59)$ & $(1.04)$ & $(1.56)$ & $(0.90)$ \\
\hline \multirow[t]{2}{*}{ Business plan $_{\mathrm{t}-1}$} & & & $0.032 * * *$ & & $0.032 * * *$ & \\
\hline & & & $(3.98)$ & & (3.73) & \\
\hline \multicolumn{7}{|l|}{ Fixed effects } \\
\hline Legal status & Yes & No & Yes & No & Yes & Yes \\
\hline Region & Yes & Yes & Yes & Yes & Yes & Yes \\
\hline Sector & Yes & Yes & Yes & Yes & Yes & Yes \\
\hline
\end{tabular}


Table 5 (continued)

\begin{tabular}{|c|c|c|c|c|c|c|}
\hline & \multicolumn{2}{|l|}{ Model 1} & \multicolumn{2}{|l|}{ Model 2} & \multicolumn{2}{|l|}{ Model 3} \\
\hline & Selection & Outcome & Selection & Outcome & Selection & Outcome \\
\hline Year & Yes & Yes & Yes & Yes & Yes & Yes \\
\hline \multirow[t]{2}{*}{ Athrho } & $1.123 * * *$ & & $0.745^{*}$ & & 0.484 & \\
\hline & $(3.19)$ & & $(1.72)$ & & $(1.24)$ & \\
\hline$\rho$ & 16008.000 & & 12967.000 & & 12967.000 & \\
\hline$N$ & 3282.000 & & 2679.000 & & 2679.000 & \\
\hline Selected & 12726.000 & & 10288.000 & & 10288.000 & \\
\hline Nonselected & 0.809 & & 0.632 & & 0.450 & \\
\hline $\begin{array}{l}\text { Log pseudolikeli- } \\
\text { hood }\end{array}$ & -10163.170 & & -7890.940 & & -7887.576 & \\
\hline $\begin{array}{l}\text { Wald test of indep. } \\
\text { Eqns }(\rho=0)\end{array}$ & 10.202 & & 2.970 & & 1.539 & \\
\hline Prob > chi 2 & 0.001 & & 0.085 & & 0.215 & \\
\hline
\end{tabular}

This table present the marginal effects from a Heckman probit model with sample selection (Van de Ven \& Van Praag, 1981) which is estimated using the Stata 'Heckprobit' routine (StataCorp, 2019). The selection equation relates to the probability of needing finance. The outcome equation relates to the probability of being a discouraged borrower conditional on needing finance. All regressions include a constant term. The exclusion restriction used in the selection equation is business plan and legal status dummy variables in models 1-2 and only business plan dummy in model 3. The excluded variables for control variables are zero employees (size), 0-5 years (business age), 18-30 years old (owner's age) and decreased (turnover change). Z-statistics adjusted for clustering at firm level are reported in parentheses. $* * *, * *$ and $*$ Significant at the $1 \%, 5 \%$ and $10 \%$ levels, respectively

on the treated (ATET) for the three groups of SMEs: innovator (product and/or process), product innovator and process innovator. Control group includes non-innovators (product and/or process), non-product innovators and non-process innovators. We observe that ATETs are positive and statistically significant for all types of innovators. Considering the results in the first column, for a SME, on average, the effect of being innovative (product and/or process) increases the likelihood of being a discouraged borrower by around 5.2 to $6.6 \%$ compared with what would have occurred if none of these firms had been innovative. Results for product innovators are consistent with those obtained previously.

\subsection{Main reasons for discouragement and innovative activity}

In this final section, we provide new evidence regarding the relationship between innovation and borrower discouragement, based upon the specific reasons for discouragement reported by SMEs in the LSBS survey. The small sample size of firms reporting discouragement and complexity of implementing a double selection Heckman multinomial model to investigate this issue makes the use of propensity score matching a good tool to shed some light on this matter for the first time.

Table 10 summarises the ATET results for three groups of SMEs: innovator (product and/or process), product innovator and process innovator. Control groups for each treated group include non-innovators (product and/or process), non-product innovators and non-process innovators, respectively. The results suggest that innovators (product/process) and product innovators are more likely to be discouraged due to a fear of rejection relative to non-innovative and nonproduct innovative counterparts. Interestingly, reluctance to take on additional risk, the timing of the decision to apply and perceived transaction costs (i.e. the decision would have taken too long/too much hassle) appear to be three additional important factors contributing to borrower discouragement across innovative SMEs. The role played by 'informal turndowns' by banks in the context of innovative SMEs certainly warrants further research (see Rostamkalaei et al., 2020).

\section{Discussion and conclusions}

This study provides important insights into the incidence and nature of borrower discouragement in SMEs. It adds 
Table 6 Heckman probit results. The impact of process innovation on being a discouraged borrower

\begin{tabular}{|c|c|c|c|c|c|c|}
\hline & \multicolumn{2}{|l|}{ Model 1} & \multicolumn{2}{|l|}{ Model 2} & \multicolumn{2}{|l|}{ Model 3} \\
\hline & Selection & Outcome & Selection & Outcome & Selection & Outcome \\
\hline \multirow{2}{*}{$\begin{array}{l}\text { Innovative firm } \\
\text { (process/prod- } \\
\text { uct) }{ }_{\mathrm{t}-1}\end{array}$} & $0.069 * * *$ & & $0.041 * * *$ & & $0.041 * * *$ & \\
\hline & (9.77) & & $(5.33)$ & & $(5.32)$ & \\
\hline \multirow{2}{*}{$\begin{array}{l}\text { Product innovator } \\
\quad \text { (pure) }{ }_{t-1}\end{array}$} & & $0.161 * * *$ & & $0.073 * *$ & & $0.062 * *$ \\
\hline & & $(5.53)$ & & $(2.50)$ & & (2.18) \\
\hline \multirow{2}{*}{$\begin{array}{l}\text { Process innovator } \\
\quad(\text { pure })_{t-1}\end{array}$} & & $0.118 * * *$ & & 0.061 & & 0.050 \\
\hline & & $(2.75)$ & & $(1.42)$ & & $(1.22)$ \\
\hline \multirow{2}{*}{$\begin{array}{l}\text { Product and } \\
\text { process innova- } \\
\text { tor }_{\mathrm{t}-1}\end{array}$} & & $0.153 * * *$ & & $0.097 * * *$ & & $0.085 * * *$ \\
\hline & & $(5.37)$ & & (3.18) & & $(2.88)$ \\
\hline \multirow[t]{2}{*}{ Aims to grow ${ }_{t-1}$} & & & $0.085 * * *$ & -0.010 & $0.085 * * *$ & -0.007 \\
\hline & & & $(10.00)$ & $(-0.37)$ & $(10.05)$ & $(-0.27)$ \\
\hline \multirow[t]{2}{*}{ Size $_{\mathrm{t}-1}:$ micro } & & & $0.037 * * *$ & -0.026 & $0.039 * * *$ & -0.011 \\
\hline & & & $(3.63)$ & $(-0.85)$ & $(3.82)$ & $(-0.36)$ \\
\hline \multirow[t]{2}{*}{ Size $_{\mathrm{t}-1}:$ small } & & & $0.075^{* * *}$ & $-0.132 * * *$ & $0.078 * * *$ & $-0.111 * * *$ \\
\hline & & & $(5.94)$ & $(-4.05)$ & $(6.17)$ & $(-3.32)$ \\
\hline \multirow{2}{*}{ Size $_{\mathrm{t}-1}:$ medium } & & & $0.090 * * *$ & $-0.226 * * *$ & $0.094 * * *$ & $-0.203 * * *$ \\
\hline & & & $(5.82)$ & $(-6.47)$ & $(5.98)$ & $(-5.53)$ \\
\hline \multirow{2}{*}{$\begin{array}{l}\text { Business age }_{\mathrm{t}-1} \text { : } \\
6-10 \text { years }\end{array}$} & & & 0.007 & 0.021 & 0.006 & 0.021 \\
\hline & & & $(0.44)$ & $(0.52)$ & $(0.40)$ & $(0.50)$ \\
\hline \multirow{2}{*}{$\begin{array}{c}\text { Business age }_{t-1} \text { : } \\
11-20 \text { years }\end{array}$} & & & -0.014 & 0.039 & -0.014 & 0.036 \\
\hline & & & $(-0.86)$ & $(0.96)$ & $(-0.89)$ & $(0.89)$ \\
\hline \multirow{2}{*}{$\begin{array}{l}\text { Business age }_{t-1}: \\
20+\text { years }\end{array}$} & & & -0.017 & -0.013 & -0.017 & -0.017 \\
\hline & & & $(-1.14)$ & $(-0.34)$ & $(-1.18)$ & $(-0.47)$ \\
\hline \multirow{2}{*}{$\begin{array}{l}\text { Turnover change } \\
\text { (stayed the } \\
\text { same) } t-1\end{array}$} & & & $-0.035^{* * *}$ & $-0.081 * * *$ & $-0.035 * * *$ & $-0.081 * * *$ \\
\hline & & & $(-3.33)$ & $(-3.05)$ & $(-3.34)$ & $(-3.06)$ \\
\hline \multirow{2}{*}{$\begin{array}{l}\text { Turnover change } \\
\text { (increased) } t-1\end{array}$} & & & -0.004 & $-0.132 * * *$ & -0.004 & $-0.131 * * *$ \\
\hline & & & $(-0.38)$ & $(-4.73)$ & $(-0.38)$ & $(-4.74)$ \\
\hline \multirow[t]{2}{*}{ Profit $_{t-1}$} & & & $-0.138 * * *$ & $-0.152 * * *$ & $-0.138 * * *$ & $-0.152 * * *$ \\
\hline & & & $(-10.70)$ & $(-6.04)$ & $(-10.69)$ & $(-6.04)$ \\
\hline \multirow{2}{*}{$\begin{array}{l}\text { Location }_{\mathrm{t}}: \text { urban } \\
\text { area }\end{array}$} & & & -0.011 & -0.022 & -0.011 & -0.021 \\
\hline & & & $(-1.17)$ & $(-0.94)$ & $(-1.17)$ & $(-0.90)$ \\
\hline \multirow[t]{2}{*}{ Female led ${ }_{t-1}$} & & & 0.004 & 0.006 & 0.003 & 0.002 \\
\hline & & & $(0.34)$ & $(0.22)$ & $(0.28)$ & $(0.08)$ \\
\hline $\begin{array}{l}\text { Minority ethnic } \\
\text { led } \\
t-1\end{array}$ & & & $0.086^{* * *}$ & $0.129 * * *$ & $0.086^{* * * *}$ & $0.131 * * *$ \\
\hline
\end{tabular}


Table 6 (continued)

\begin{tabular}{|c|c|c|c|c|c|c|}
\hline & \multicolumn{2}{|l|}{ Model 1} & \multicolumn{2}{|l|}{ Model 2} & \multicolumn{2}{|l|}{ Model 3} \\
\hline & Selection & Outcome & Selection & Outcome & Selection & Outcome \\
\hline & & & $(3.84)$ & $(2.93)$ & $(3.84)$ & $(2.97)$ \\
\hline \multirow[t]{2}{*}{ Family owned ${ }_{t-1}$} & & & 0.016 & 0.027 & 0.016 & 0.023 \\
\hline & & & $(1.62)$ & $(1.04)$ & $(1.60)$ & $(0.89)$ \\
\hline \multirow[t]{2}{*}{ Business plan ${ }_{t-1}$} & & & $0.032 * * *$ & & $0.033 * * *$ & \\
\hline & & & $(4.06)$ & & $(4.13)$ & \\
\hline \multicolumn{7}{|l|}{ Fixed effects } \\
\hline Legal status & Yes & No & Yes & No & Yes & Yes \\
\hline Region & Yes & Yes & Yes & Yes & Yes & Yes \\
\hline Sector & Yes & Yes & Yes & Yes & Yes & Yes \\
\hline Year & Yes & Yes & Yes & Yes & Yes & Yes \\
\hline \multirow[t]{2}{*}{ Athrho } & $2.259 * * *$ & & $1.227 * * *$ & & $0.972 * * *$ & \\
\hline & $(4.32)$ & & $(3.47)$ & & $(3.04)$ & \\
\hline$\rho$ & 16022.000 & & 12976.000 & & 12976.000 & \\
\hline$N$ & 3296.000 & & 2688.000 & & 2688.000 & \\
\hline Selected & 12726.000 & & 10288.000 & & 10288.000 & \\
\hline Nonselected & 0.978 & & 0.842 & & 0.750 & \\
\hline $\begin{array}{l}\text { Log pseudolikeli- } \\
\text { hood }\end{array}$ & -10178.933 & & -7906.263 & & -7903.687 & \\
\hline $\begin{array}{l}\text { Wald test of } \\
\text { indep. Eqns ( } \rho \\
=0)\end{array}$ & 18.625 & & 12.067 & & 9.256 & \\
\hline Prob $>$ chi 2 & 0.000 & & 0.001 & & 0.002 & \\
\hline
\end{tabular}

This table present the marginal effects from a Heckman probit model with sample selection (Van de Ven \& Van Praag, 1981) which is estimated using the Stata 'Heckprobit' routine (StataCorp, 2019). The selection equation relates to the probability of needing finance. The outcome equation relates to the probability of being a discouraged borrower conditional on needing finance. All regressions include a constant term. The exclusion restriction used in the selection equation is business plan and legal status dummy variables in models 1-2 and only business plan dummy in model 3. The excluded variables for control variables are zero employees (size), 0-5 years (business age), 18-30 years old (owner's age) and decreased (turnover change). Z-statistics adjusted for clustering at firm level are reported in parentheses. $* * * * *$ and $*$ Significant at the $1 \%, 5 \%$ and $10 \%$ levels, respectively

an important new dimension to the growing literature on innovative small firms by examining the problem of credit self-rationing in the UK SMEs. According to Schumpeter, entrepreneurship consists of 'getting things done' (Schumpeter, 1934, p.93). If borrower discouragement prevents entrepreneurs from undertaking growthoriented activities, there are strong grounds to suggest much greater academic, and policy attention should be directed toward understanding both the causes and consequences of this complex phenomenon.

We adopt a more expansive definition of borrower discouragement, augmenting prior studies, which typically adopt a narrow definition of borrower discouragement (i.e. due to a fear of rejection) thus underestimating the true extent of credit self-rationing. As such, we find that the overall incidence of borrower discouragement across SMEs is much higher than the levels reported in prior UK studies (Cowling et al., 2016; Rostamkalaei, 2017). ${ }^{11}$ The rich nature of the LSBS dataset used in this study suggests that borrower discouragement is a multi-faceted phenomenon with multiple underlying determinants. However, the lack of specific metrics to identify the creditworthiness of discouraged SMEs is a limitation of the LSBS survey and certainly an issue meriting further academic enquiry.

The results of our empirical analysis also suggest that SMEs engaging in innovation are much more

\footnotetext{
$\overline{11}$ Given approximately one in ten SMEs in our sample were affected, this could infer as many as 500,000 UK SMEs fall into the category of discouraged borrowers.
} 
Table 7 Heckman probit results. The impact of novelty of product innovation on being a discouraged borrower

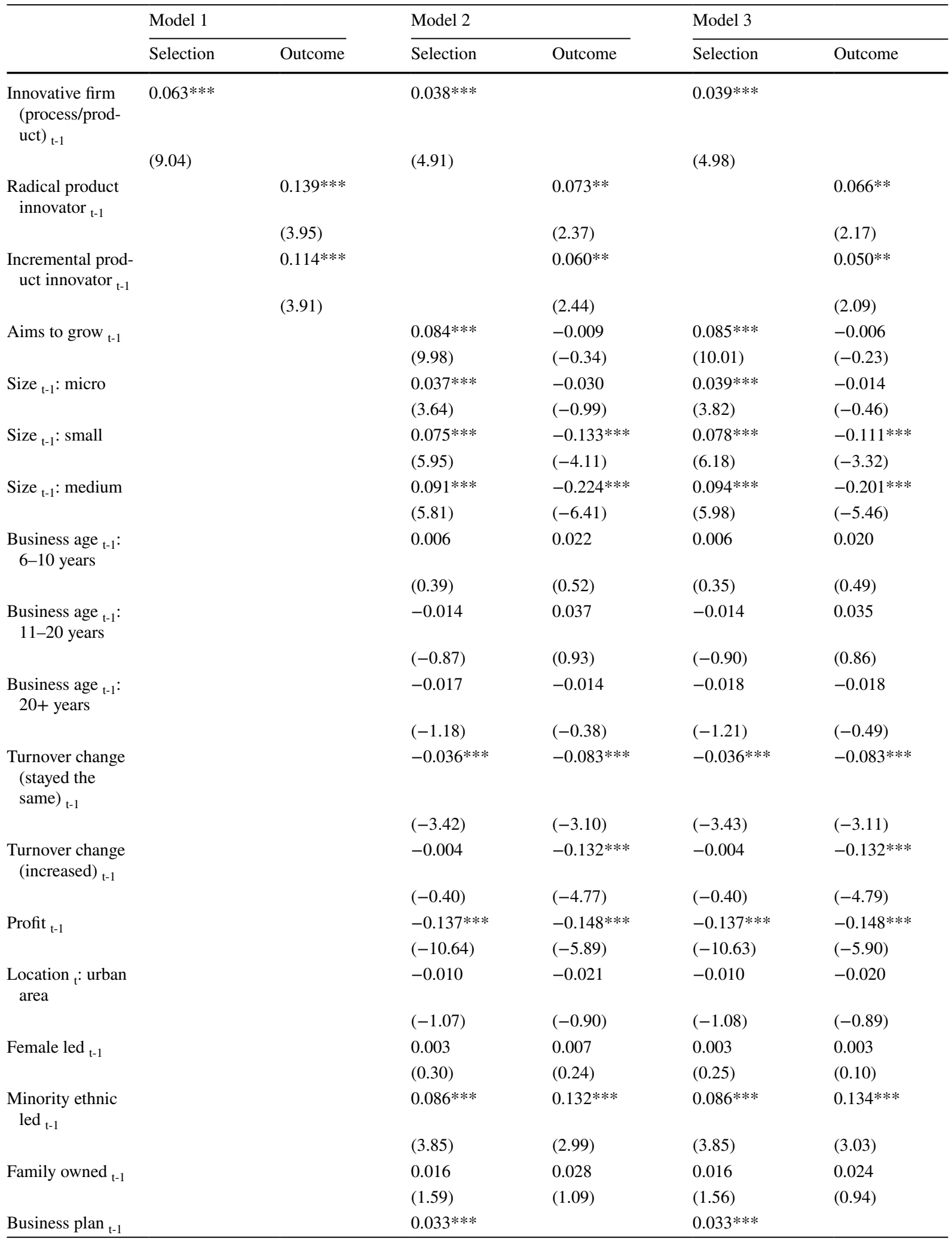


Table 7 (continued)

\begin{tabular}{|c|c|c|c|c|c|c|}
\hline & \multicolumn{2}{|l|}{ Model 1} & \multicolumn{2}{|l|}{ Model 2} & \multicolumn{2}{|l|}{ Model 3} \\
\hline & Selection & Outcome & Selection & Outcome & Selection & Outcome \\
\hline & & & $(4.11)$ & & $(4.07)$ & \\
\hline \multicolumn{7}{|l|}{ Fixed effects } \\
\hline Legal status & Yes & No & Yes & No & Yes & Yes \\
\hline Region & Yes & Yes & Yes & Yes & Yes & Yes \\
\hline Sector & Yes & Yes & Yes & Yes & Yes & Yes \\
\hline Year & Yes & Yes & Yes & Yes & Yes & Yes \\
\hline \multirow[t]{2}{*}{ Athrho } & $1.862 * * *$ & & $1.000 * * *$ & & $0.770 * *$ & \\
\hline & $(3.25)$ & & $(2.83)$ & & $(2.34)$ & \\
\hline$\rho$ & 16008.000 & & 12966.000 & & 12966.000 & \\
\hline$N$ & 3282.000 & & 2678.000 & & 2678.000 & \\
\hline Selected & 12726.000 & & 10288.000 & & 10288.000 & \\
\hline Nonselected & 0.953 & & 0.762 & & 0.647 & \\
\hline $\begin{array}{l}\text { Log pseudolikeli- } \\
\text { hood }\end{array}$ & -10154.235 & & -7889.536 & & -7886.918 & \\
\hline $\begin{array}{l}\text { Wald test of } \\
\text { indep. Eqns }(\rho \\
=0)\end{array}$ & 10.563 & & 8.000 & & 5.459 & \\
\hline Prob > chi2 & 0.001 & & 0.005 & & 0.019 & \\
\hline
\end{tabular}

This table present the marginal effects from a Heckman probit model with sample selection (Van de Ven \& Van Praag, 1981) which is estimated using the Stata 'Heckprobit' routine (StataCorp, 2019). The selection equation relates to the probability of needing finance. The outcome equation relates to the probability of being a discouraged borrower conditional on needing finance. All regressions include a constant term. The exclusion restriction used in the selection equation is business plan and legal status dummy variables in models 1-2 and only business plan dummy in model 3. The excluded variables for control variables are zero employees (size), 0-5 years (business age), 18-30 years old (owner's age) and decreased (turnover change). Z-statistics adjusted for clustering at firm level are reported in parentheses. $* * *, * *$ and $*$ Significant at the $1 \%, 5 \%$ and $10 \%$ levels, respectively

likely to be discouraged borrowers. This is especially true for SMEs undertaking the riskiest form of innovation (product innovation). In other words, the more innovative a SME is, the more likely they self-ration credit. As such, we augment and complement evidence highlighting the structural problems impacting the supply and demand of finance for innovative SMEs (Lee et al., 2015) with new evidence suggesting that radically innovative firms are also those most likely to self-impose credit constraints by refraining from external finance applications.

From a theoretical perspective, our findings regarding which types of firm are most likely to be discouraged borrowers are also largely consistent with informational theories of firm-level borrowing discussed earlier. These theories suggest that SMEs are likely to encounter credit restrictions and that these will be amplified for the most informationally opaque and risky firms (with limited collateral, volatile cash flows and higher proportions of intangible assets). It may be the case that innovative SMEs are acutely aware of their own risky status and consequently self-ration debt finance. Indeed, this is often an explanation provided by policymakers for this phenomenon (BEIS, 2017). ${ }^{12}$ Moreover, and in line with the theoretical expectations discussed earlier, one plausible explanation for the higher incidence of borrower discouragement across radical innovators owes to the greater levels of absolute uncertainty associated with these types of innovations (O'Connor \& Rice, 2013). Incremental innovations on the other hand are associated with lower levels of uncertainty and consequently easier to assess ex-ante.

\footnotetext{
12 Indeed, a study by the UK Department for Business Energy and Industrial Strategy claims the main reason for borrower discouragement amongst innovative firms was 'because of recognition of the risk involved which they [SMEs] believed potential investors would often not be prepared to take on' (BEIS, 2017, p. 133).
} 
Table 8 Heckman probit results. The impact of novelty of process innovation on being a discouraged borrower

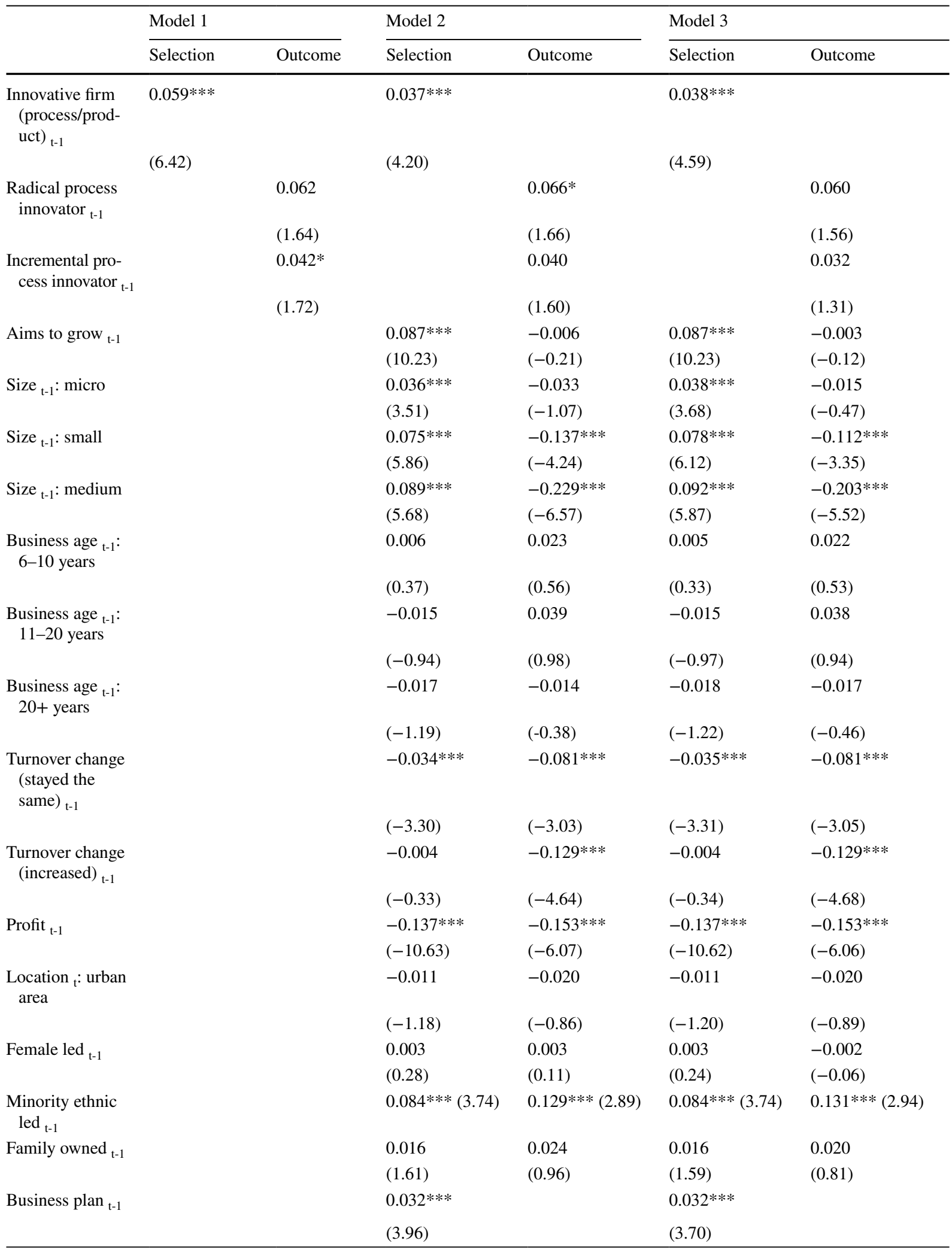


Table 8 (continued)

\begin{tabular}{|c|c|c|c|c|c|c|}
\hline & \multicolumn{2}{|l|}{ Model 1} & \multicolumn{2}{|l|}{ Model 2} & \multicolumn{2}{|l|}{ Model 3} \\
\hline & Selection & Outcome & Selection & Outcome & Selection & Outcome \\
\hline \multicolumn{7}{|l|}{ Fixed effects } \\
\hline Legal status & Yes & No & Yes & No & Yes & Yes \\
\hline Region & Yes & Yes & Yes & Yes & Yes & Yes \\
\hline Sector & Yes & Yes & Yes & Yes & Yes & Yes \\
\hline Year & Yes & Yes & Yes & Yes & Yes & Yes \\
\hline \multirow[t]{2}{*}{ Athrho } & $1.141 * * *$ & & $0.777 *$ & & 0.492 & \\
\hline & (3.19) & & $(1.81)$ & & $(1.27)$ & \\
\hline$\rho$ & 15999.000 & & 12959.000 & & 12959.000 & \\
\hline$N$ & 3273.000 & & 2671.000 & & 2671.000 & \\
\hline Selected & 12726.000 & & 10288.000 & & 10288.000 & \\
\hline Nonselected & 0.815 & & 0.651 & & 0.456 & \\
\hline $\begin{array}{l}\text { Log pseudolikeli- } \\
\text { hood }\end{array}$ & -10143.524 & & -7876.186 & & -7872.708 & \\
\hline $\begin{array}{l}\text { Wald test of indep. } \\
\text { Eqns }(\rho=0)\end{array}$ & 10.197 & & 3.292 & & 1.605 & \\
\hline Prob > chi2 & 0.001 & & 0.070 & & 0.205 & \\
\hline
\end{tabular}

This table present the marginal effects from a Heckman probit model with sample selection (Van de Ven \& Van Praag, 1981) which is estimated using the Stata 'Heckprobit' routine (StataCorp, 2019). The selection equation relates to the probability of needing finance. The outcome equation relates to the probability of being a discouraged borrower conditional on needing finance. All regressions include a constant term. The exclusion restriction used in the selection equation is business plan and legal status dummy variables in models 1-2 and only business plan dummy in model 3. The excluded variables for control variables are zero employees (size), 0-5 years (business age), 18-30 years old (owner's age) and decreased (turnover change). Z-statistics adjusted for clustering at firm level are reported in parentheses. $* * * * *$ and $*$ Significant at the $1 \%, 5 \%$ and $10 \%$ levels, respectively

Table 9 Propensity score matching: average treatment effect on the treated (ATET) of being an innovative SME on the likelihood of being discouraged borrower

Panel A: One match per observation

\begin{tabular}{|c|c|c|c|}
\hline \multirow[t]{2}{*}{ ATET } & $0.052 * * *$ & $0.081 * * *$ & $0.057 * * *$ \\
\hline & $(3.71)$ & $(5.58)$ & $(3.82)$ \\
\hline$N$ & 8,026 & 8,017 & 7,984 \\
\hline
\end{tabular}

Panel B: Four matches per observation

$\begin{array}{cccc}\text { ATET } & 0.066^{* * *} & 0.067 * * * & 0.065^{* * *} \\ & (5.53) & (5.48) & (5.22) \\ N & 8,026 & 8,017 & 7,984 \\ \text { Panel C: Eight matches per observation } & & 0.060^{* * *} \\ \text { ATET } & 0.062^{* * *} & 0.062^{* * *} & (5.02) \\ N & (5.48) & (5.30) & 7,984\end{array}$

This table shows the computation of the average treatment effect of the treated (ATET). That is, for a SME, on average, the effect of being innovative on the likelihood of being discouraged borrower. We match innovative firms with one (panel A), four (panel B) and eight corresponding (panel C) non-innovative firms. Robust z-statistics are reported in parentheses. $* * *, * *$ and $*$ denotes statistical significance at the $1 \%, 5 \%$ and $10 \%$ levels, respectively 
Table 10 Propensity score matching: average treatment effect on the treated (ATET) of being an innovative SME on the likelihood of being discouraged borrower
This table shows the computation of the average treatment effect of the treated (ATET). That is, for a SME, on average, the effect of being innovative on the likelihood of being discouraged borrower. We match innovative firms with one corresponding noninnovative firms. Robust $\mathrm{Z}$-statistics are reported in parentheses. $* * *$, ** and $*$ denotes statistical significance at the $1 \%, 5 \%$ and $10 \%$ levels, respectively

\begin{tabular}{|c|c|c|c|}
\hline & Innovator (product/process) & Product innovator & Process Innovator \\
\hline \multicolumn{4}{|c|}{ D1: You thought you would be rejected } \\
\hline \multirow[t]{2}{*}{ ATET } & $0.041 * * *$ & $0.028 * * *$ & 0.003 \\
\hline & $(4.72)$ & $(2.60)$ & $(0.26)$ \\
\hline$N$ & 5439 & 5435 & 5413 \\
\hline \multicolumn{4}{|c|}{ D2: You thought it would be too expensive } \\
\hline \multirow[t]{2}{*}{ ATET } & 0.010 & $0.017^{*}$ & $0.017 *$ \\
\hline & $(1.06)$ & $(1.84)$ & $(1.72)$ \\
\hline$N$ & 5335 & 5331 & 5311 \\
\hline \multicolumn{4}{|c|}{ D3: You don't want to take on additional risk } \\
\hline \multirow[t]{2}{*}{ ATET } & $0.036 * * *$ & $0.044 * * *$ & $0.034 * * *$ \\
\hline & $(3.21)$ & $(3.74)$ & $(2.75)$ \\
\hline$N$ & 5660 & 5656 & 5637 \\
\hline \multicolumn{4}{|c|}{ D4: Now is not the right time because of economic conditions } \\
\hline \multirow[t]{2}{*}{ ATET } & $0.016^{* *}$ & $0.020 * * *$ & 0.004 \\
\hline & $(2.39)$ & $(2.84)$ & $(0.51)$ \\
\hline$N$ & 5201 & 5197 & 5176 \\
\hline \multicolumn{4}{|c|}{ D5: You didn't know where to find the appropriate finance you needed } \\
\hline \multirow[t]{2}{*}{ ATET } & 0.007 & 0.001 & -0.000 \\
\hline & $(1.25)$ & $(0.23)$ & $(-0.04)$ \\
\hline$N$ & 5040 & 5036 & 5016 \\
\hline \multicolumn{4}{|c|}{ D6: Poor credit history } \\
\hline \multirow[t]{2}{*}{ ATET } & 0.006 & 0.005 & -0.002 \\
\hline & $(1.24)$ & $(0.98)$ & $(-0.41)$ \\
\hline$N$ & 5044 & 5040 & 5019 \\
\hline \multicolumn{4}{|c|}{ D7: The decision would have taken too long/too much hassle } \\
\hline \multirow[t]{2}{*}{ ATET } & $0.043 * * *$ & $0.042 * * *$ & $0.032 * * *$ \\
\hline & $(5.60)$ & $(5.37)$ & $(3.33)$ \\
\hline$N$ & 5277 & 5272 & 5251 \\
\hline \multicolumn{4}{|c|}{ D8: Other/don't know } \\
\hline \multirow[t]{2}{*}{ ATET } & 0.014 & 0.003 & 0.011 \\
\hline & $(1.22)$ & $(0.22)$ & $(0.94)$ \\
\hline$N$ & 5527 & 5519 & 5497 \\
\hline
\end{tabular}

Theoretically, we can also speculate that one outcome of discouragement may result in increased levels of 'bricolage' in these resource-constrained innovative SMEs. A stream of work on bricolage and innovation has investigated patterns of behaviour and organisational processes (i.e. making do with what is at hand, creating something from nothing and experimenting by combining resources for new purposes) enabling resource-constrained entrepreneurs to exploit their potential by making creative use of their limited resources to innovate (Baker \& Nelson, 2005). While this improvisational process may allow some firms to innovate despite attendant resource constraints (Senyard et al., 2014), excessive use of bricolage may eventually hinder product development effectiveness in the longer term (Moorman \& Miner, 1998). Consequently, if firms rely excessively on bricolage, the proliferation of sub-standard solutions and limited resources directed at improving 'stop gaps' and repetitive 'making do' may 'reduce or even fully offset the positive effects of bricolage on innovativeness' (Senyard et al., 2014, p.216).

The findings presented in this paper are relevant for practitioners and policymakers alike. While problems accessing finance are often used to justify government intervention toward small innovative firms, 
frequently these policy efforts focus upon the provision of supply-side measures such as credit guarantee schemes, grants and public equity finance instruments (Bloom et al., 2019; Schneider \& Veugelers, 2010). By comparison, the issue of insufficient demand and credit self-rationing is rarely discussed in policy documents or addressed explicitly via targeted policy initiatives. This appears to be a crucial oversight. Given the potential sub-optimal economic outcomes resulting from borrower discouragement (Cowling et al., 2016; Hutton $\&$ Nightingale, 2011), more concerted policy efforts to alleviate borrower discouragement appear appropriate.

Fittingly, there appears to be indicative evidence that the traditional supply-side approach to policy may be gradually shifting. Indeed, in light of the recent declining levels of demand for bank finance across UK SMEs, the British Business Bank recently launched a Demand Development Unit to help SMEs better understand and identify suitable sources of finance (British Business Bank, 2020). This seems a desirable step, given that a lack of awareness of different funding options together with an over-reliance on their main bank may explain why SMEs become discouraged borrowers in the first place (Wernli \& Dietrich, 2021). Another approach would be to offer de novo start-ups free financial advice on different funding sources and financial products which are often difficult to comprehend by time-constrained entrepreneurs. ${ }^{13}$ Access to information regarding external sources of finance for start-ups and SMEs can be helpful for enabling entrepreneurs to access the right type of financing for their ventures (Wilson, 2015). An additional benefit of such informational support is its inexpensive nature and ease of operation.

Overall, the results of this study suggest a need for a greater policy emphasis on alleviating borrower discouragement within innovative SMEs and a closer alignment between innovation and SME finance policy initiatives. Going forward, policymakers (such as the UK British Business Bank) could pro-actively target these informational initiatives toward the types of innovative SMEs examined herein. ${ }^{14}$ Using evidence

\footnotetext{
13 This suggestion would help address the $10.6 \%$ of discouraged borrowers who claimed they had too little time or thought it involved 'too much hassle' to apply for finance even if they need it (see Figure A1).

14 Often SMEs are unaware of schemes aimed at tackling borrower discouragement such as loan guarantees (Wernli \& Dietrich, 2021).
}

such as the survey data utilised in this paper, stateowned banks could potentially monitor borrower discouragement on an ongoing basis in order to assess how these types of policies are performing over time. In addition, targeted measures can be used to improve access of external finance for innovative SMEs including the use of loan guarantee schemes and public guarantees for innovative firms. Those measures could contribute to increase the loan supply for SMEs by decreasing the perceived risks of innovative SMEs and improving access to both debt and equity finance. These policy measures may have equal applicability elsewhere given a high incidence of borrower discouragement prevalent in the USA and other European countries.

Acknowledgements We gratefully acknowledge the ESRCfunded Enterprise Research Centre for funding for this study. We wish to pay special thanks to Sumit Rahman and Frances Pottier (from the Department for Business, Energy and Industrial Strategy) for providing access to the Longitudinal Small Business Survey for this project. We are also grateful to Steve Roper, Phil Molyneux and Jerry Coakley for valuable comments and suggestions on previous versions of the manuscript. The authors' also wish to pay thanks to the excellent feedback from the reviewers which has undoubtedly helped to strengthen the paper considerably. The usual disclaimer applies.

Open Access This article is licensed under a Creative Commons Attribution 4.0 International License, which permits use, sharing, adaptation, distribution and reproduction in any medium or format, as long as you give appropriate credit to the original author(s) and the source, provide a link to the Creative Commons licence, and indicate if changes were made. The images or other third party material in this article are included in the article's Creative Commons licence, unless indicated otherwise in a credit line to the material. If material is not included in the article's Creative Commons licence and your intended use is not permitted by statutory regulation or exceeds the permitted use, you will need to obtain permission directly from the copyright holder. To view a copy of this licence, visit http://creativecommons.org/licenses/by/4.0/.

\section{References}

Beck, M., Lopes-Bento, C., \& Schenker-Wicki, A. (2016). Radical or incremental: Where does R\&D policy hit? Research Policy, 45(4), 869-883. https://doi.org/10. 1016/j.respol.2016.01.010

Baker, T., \& Nelson, R. E. (2005). Creating something from nothing: Resource construction through entrepreneurial bricolage. Administrative Science Quarterly, 50(3), 329366. https://doi.org/10.2189/asqu.2005.50.3.329

Berger, A. N., \& Udell, G. F. (1998). The economics of small business finance: The roles of private equity and debt markets in the financial growth cycle. Journal of Banking 
\& Finance, 22(6-8), 613-673. https://doi.org/10.1016/ S0378-4266(98)00038-7

Berger, A. N., \& Udell, G. F. (2006). A more complete conceptual framework for SME finance. Journal of Banking \& Finance, 30(11), 2945-2966. https://doi.org/10.1016/j. jbankfin.2006.05.008

BEIS (2017) The innovative firm's journey to finance, BEIS Research Paper Number 23.

Bloom, N., Van Reenen, J., \& Williams, H. (2019). A toolkit of policies to promote innovation. Journal of Economic Perspectives, 33(3), 163-184. https://doi.org/10.1257/jep. 33.3.163

British Business Bank (2020) Small Business Finance Markets 2019/20. https://www.british-business-bank.co.uk/wpcontent/uploads/2020/02/Small-Business-Finance-Marke ts-2019-20-report-FINAL.pdf

Brown, R., \& Lee, N. (2019). Strapped for cash? Funding for UK high growth SMEs since the global financial crisis. Journal of Business Research, 99, 37-45. https://doi.org/ 10.1016/j.jbusres.2019.02.001

Calabrese, R., Girardone, C., \& Sclip, A. (2020). Financial fragmentation and SMEs' access to finance. Small Business Economics, 1-25. https://doi.org/10.1007/ s11187-020-00393-1

Cameron, A. C., \& Trivedi, K. P. (2005). Microeconometrics: Methods and applications. Cambridge University Press.

Chakravarty, S., \& Xiang, M. (2013). The international evidence on discouraged small businesses. Journal of Empirical Finance, 20, 63-82.

Czarnitzki, D., \& Hottenrott, H. (2011). Financial constraints: Routine versus cutting edge R\&D investment. Journal of Economics \& Management Strategy, 20(1), 121-157. https://doi.org/10.1111/j.1530-9134.2010.00285.x

Cassar, G. (2004). The financing of business start-ups. Journal of Business Venturing, 19(2), 261-283. https://doi.org/10. 1016/S0883-9026(03)00029-6

Cavalluzzo, K. S., Cavalluzzo, L. C., \& Wolken, J. D. (2002). Competition, small business financing, and discrimination: Evidence from a new survey. Journal of Business, 75(4), 641-679. https://doi.org/10.1086/341638

Christensen, J. L., \& Hain, D. S. (2014). Scared away? Discouraged borrowers and capital market information. In ISBE Conference 2014: Inspire, share, learn.

Coad, A., \& Rao, R. (2008). Innovation and firm growth in high-tech sectors: A quantile regression approach. Research Policy, 37(4), 633-648. https://doi.org/10. 1016/j.respol.2008.01.003

Cole, R., \& Sokolyk, T. (2016). Who needs credit and who gets credit? Evidence from the surveys of small business finances. Journal of Financial Stability, 24, 40-60. https:// doi.org/10.1016/j.jfs.2016.04.002

Cosh, A., Cumming, D., \& Hughes, A. (2009). Outside entrepreneurial capital. The Economic Journal, 119(540), 1494-1533. https://doi.org/10.1111/j.1468-0297.2009. 02270.x.

Cowling, M., Liu, W., Minniti, M., \& Zhang, N. (2016). UK credit and discouragement during the GFC. Small Business Economics, 47(4), 1049-1074. https://doi.org/10. 1007/s11187-016-9745-6

Cumming, D., Meoli, M., \& Vismara, S. (2021). Does equity crowdfunding democratize entrepreneurial finance?
Small Business Economics, 56(2), 533-552. https://doi. org/10.1007/s11187-019-00188-z

Ferrando, A., \& Mulier, K. (2015). The real effects of credit constraints: evidence from discouraged borrowers in the euro area. European Central Bank Working Paper, 1842.

Fraser, S. (2004) Finance for Small and Medium-Sized Enterprises: A Report on the 2004 UK Survey of SME Finances, Centre for Small and Medium-Sized Enterprises. Warwick Business School, Warwick.

Fraser, S. (2009). Is there ethnic discrimination in the UK market for small business credit? International Small Business Journal, 27(5), 583-607. https://doi.org/10. $1177 / 0266242609338756$

Fraser, S. (2014). Back to borrowing? Perspectives on the arc of discouragement. Enterprise Research Centre, White Paper, 8.

Fraser, S., Bhaumik, S. K., \& Wright, M. (2015). What do we know about entrepreneurial finance and its relationship with growth? International Small Business Journal, 33(1), 70-88. https://doi.org/10.1177/0266242614 547827

Freel, M. (2006). Patterns of technological innovation in knowledge intensive business services. Industry and Innovation, 13(3), 335-358. https://doi.org/10.1080/ 13662710600859157

Freel, M. S. (2007). Are small innovators credit rationed? Small Business Economics, 28(1), 23-35. https://doi. org/10.1007/s11187-005-6058-6

Freel, M., Carter, S., Tagg, S., \& Mason, C. (2012). The latent demand for bank debt: characterizing "discouraged borrowers". Small Business Economics, 38(4), 399-418. https://doi.org/10.1007/s11187-010-9283-6

Gama, A. P. M., Duarte, F. D., \& Esperança, J. P. (2017). Why discouraged borrowers exist? An empirical (re) examination from less developed countries. Emerging Markets Review, 33, 19-41.

Ghosal, V., \& Ye, Y. (2015). Uncertainty and the employment dynamics of small and large businesses. Small Business Economics, 44(3), 529-558. https://doi.org/10. 1007/s11187-014-9614-0

Hall, B. H., \& Lerner, J. (2010). The financing of R\&D and innovation. In Handbook of the Economics of Innovation (Vol. 1, pp. 609-639). North-Holland, Amsterdam. https://doi.org/10.1016/S0169-7218(10)01014-2

Hall, B. H., Moncada-Paternò-Castello, P., Montresor, S., \& Vezzani, A. (2016). Financing constraints, R\&D investments and innovative performances: new empirical evidence at the firm level for Europe. Journal of Innovation and New Technology, 25(3), 183-196. https://doi.org/10. 1080/10438599.2015.1076194

Han, L., Fraser, S., \& Storey, D. J. (2009). Are good or bad borrowers discouraged from applying for loans? Evidence from US small business credit markets. Journal of Banking \& Finance, 33(2), 415-424. https://doi.org/10. 1016/j.jbankfin.2008.08.014

Hutton, W., \& Nightingale, P. (2011). The Discouraged Economy. Big Innovation Centre.

Kerr, W. R., \& Nanda, R. (2015). Financing innovation. Annual Review of Financial Economics, 7, 445-462. https://doi. org/10.1146/annurev-financial-111914-041825 
King, R. G., \& Levine, R. (1993). Finance and growth: Schumpeter might be right. Quarterly Journal of Economics, 108(3), 717-737. https://doi.org/10.2307/2118406

Kon, Y., \& Storey, D. J. (2003). A theory of discouraged borrowers. Small Business Economics, 21(1), 37-49. https:// doi.org/10.1023/A:1024447603600

Knight, F. H. (1921). Risk, uncertainty and profit. Hart, Schaffner and Marx.

Lee, N., Sameen, H., \& Cowling, M. (2015). Access to finance for innovative SMEs since the financial crisis. Research Policy, 44(2), 370-380. https://doi.org/10.1016/j.respol. 2014.09.008

Lee, N., \& Brown, R. (2017). Innovation, SMEs and the liability of distance: the demand and supply of bank funding in UK peripheral regions. Journal of Economic Geography, 17(1), 233-260. https://doi.org/10.1093/jeg/lbw011

Levenson, A. R., \& Willard, K. L. (2000). Do firms get the financing they want? Measuring credit rationing experienced by small businesses in the US. Small Business Economics, 14(2), 83-94. https://doi.org/10.1023/A:10081 96002780

Liberti, J. M., \& Petersen, M. A. (2019). Information: Hard and soft. Review of Corporate Finance Studies, 8(1), 1-41. https://doi.org/10.1093/rcfs/cfy009

Lipczynski, J., Wilson, J. O. S., \& Goddard, J. (2017). Industrial Organization: Competition, Strategy and Policy (5th ed.). Pearson Education.

Love, J. H., \& Roper, S. (2015). SME innovation, exporting and growth: A review of existing evidence. International Small Business Journal, 33(1), 28-48. https://doi.org/10. $1177 / 0266242614550190$

Love, J. H., Roper, S., \& Zhou, Y. (2016). Experience, age and exporting performance in UK SMEs. International Business Review, 25(4), 806-819. https://doi.org/10.1016/j. ibusrev.2015.10.001

Mac an Bhaird, C., Vidal, J. S., \& Lucey, B. (2016). Discouraged borrowers: Evidence for Eurozone SMEs. Journal of International Financial Markets, Institutions and Money, 44, 46-55. https://doi.org/10.1016/j.intfin.2016.04.009.

Marlow, S., \& Patton, D. (2005). All credit to men? Entrepreneurship, finance, and gender. Entrepreneurship Theory and Practice, 29(6), 717-735. https://doi.org/10.1111/j. 1540-6520.2005.00105.x

Mazzucato, M. (2013). Financing innovation: creative destruction vs. destructive creation. Industrial and Corporate Change, 22(4), 851-867.

Mina, A., Lahr, H., \& Hughes, A. (2013). The demand and supply of external finance for innovative firms. Industrial and Corporate Change, 22(4), 869-901. https://doi.org/ 10.1093/icc/dtt020

Mol-Gómez-Vázquez, A., Hernández-Cánovas, G., \& KoëterKant, J. (2021). Banking stability and borrower discouragement: A multilevel analysis for SMEs in the EU-28. Small Business Economics, 1-15.

Moorman, C., \& Miner, A. S. (1998). The convergence of planning and execution: Improvisation in new product development. Journal of Marketing, 62(3), 1-20. https://doi. org/10.1177/002224299806200301

Moro, A., Wisniewski, T. P., \& Mantovani, G. M. (2017). Does a manager's gender matter when accessing credit? Evidence from European data. Journal of Banking \&
Finance, 80, 119-134. https://doi.org/10.1016/j.jbankfin. 2017.04.009

Neville, F., Forrester, J. K., O’Toole, J., \& Riding, A. (2018). Why even bother trying? Examining discouragement among racial minority entrepreneurs. Journal of Management Studies, 55(3), 424-456. https://doi.org/10.1111/ joms.12319

Nguyen, H. T., Nguyen, H. M., Troege, M., \& Nguyen, A. T. (2020). Debt aversion, education, and credit self-rationing in SMEs. Small Business Economics, 1-19. https://doi.org/ 10.1007/s11187-020-00329-9

O’Connor, G. C., \& Rice, M. P. (2013). A comprehensive model of uncertainty associated with radical innovation. Journal of Product Innovation Management, 30, 2-18. https://doi.org/10.1111/jpim.12060

OECD (2020), "The impact of COVID-19 on SME financing: A special edition of the OECD Financing SMEs and Entrepreneurs Scoreboard", OECD SME and Entrepreneurship Papers, No. 22, OECD Publishing, Paris, https:// doi.org/10.1787/ecd81a65-en.

Paunov, C. (2012). The global crisis and firms' investments in innovation. Research Policy, 41(1), 24-35. https://doi.org/ 10.1016/j.respol.2011.07.007

Qi, S., \& Nguyen, D. D. (2021). Government connections and credit access around the world: Evidence from discouraged borrowers. Journal of International Business Studies, 52(2), 321-333.

Revest, V., \& Sapio, A. (2012). Financing technology-based small firms in Europe: What do we know? Small Business Economics, 39(1), 179-205. https://doi.org/10.1007/ s11187-010-9291-6

Robb, A. M., \& Robinson, D. T. (2014). The capital structure decisions of new firms. Review of Financial Studies, 27(1), 153-179. https://doi.org/10.1093/rfs/hhs072

Rosenbaum, P. R., \& Rubin, D. B. (1983). The central role of the propensity score in observational studies for causal effects. Biometrika, 70, 41-55. https://doi.org/10.1093/ biomet/70.1.41

Rostamkalaei, A., \& Freel, M. (2016). The cost of growth: Small firms and the pricing of bank loans. Small Business Economics, 46(2), 255-272. https://doi.org/10.1007/ s11187-015-9681-x

Rostamkalaei, A. (2017). Discouraged borrowers aftermath of financial crisis: A UK study. Journal of Small Business and Enterprise Development, 24(2), 394-410. https://doi. org/10.1108/JSBED-09-2016-0137

Rostamkalaei, A., Nitani, M., \& Riding, A. (2018). Borrower discouragement: The role of informal turndowns. Small Business Economics, 1-16. https://doi.org/10.1007/ s11187-018-0086-5

Rostamkalaei, A., Nitani, M., \& Riding, A. (2020). Borrower discouragement: the role of informal turndowns. Small Business Economics, 54(1), 173-188.

Senyard, J., Baker, T., Steffens, P., \& Davidsson, P. (2014). Bricolage as a path to innovativeness for resource constrained new firms. Journal of Product Innovation Management, 31(2), 211-230. https://doi.org/10.1111/jpim.12091

Saridakis, G., Idris, B., Hansen, J. M., \& Dana, L. P. (2019). SMEs' internationalisation: When does innovation matter? Journal of Business Research, 96, 250-263. https:// doi.org/10.1016/j.jbusres.2018.11.001 
Schneider, C., \& Veugelers, R. (2010). On young highly innovative companies: Why they matter and how (not) to policy support them. Industrial and Corporate Change, 19(4), 969-1007. https://doi.org/10.1093/icc/dtp052

Schumpeter, J. (1934). The Theory of Economic Development: An Inquiry into Profits, Capital, Credit, Interest and the Business Cycle. Transaction Publishers.

Scottish Government. (2019). Scottish National Investment Bank: Fairer Scotland Duty Assessment. Scottish Government.

Tang, Y., Deng, C., \& Moro, A. (2017). Firm-bank trusting relationship and discouraged borrowers. Review of Managerial Science, 11, 519-541.

Teece, D., Peteraf, M., \& Leih, S. (2016). Dynamic capabilities and organizational agility: Risk, uncertainty, and strategy in the innovation economy. California Management Review, 58(4), 13-35. https://doi.org/10.1525/cmr.2016. 58.4.13

Van de Ven, W. P., \& Van Praag, B. M. (1981). The demand for deductibles in private health insurance: A probit model with sample selection. Journal of Econometrics, 17(2), 229-252. https://doi.org/10.1016/0304-4076(81)90028-2
Wernli, R., \& Dietrich, A. (2021). Only the brave: improving self-rationing efficiency among discouraged Swiss SMEs. Small Business Economics, 1-27. https://doi.org/10.1007/ s11187-021-00546-w

Wilson, K. E. (2015). "Policy Lessons from Financing Innovative Firms", OECD Science, Technology and Industry Policy Papers, No. 24. OECD Publishing.

Xiang, D., Worthington, A. C., \& Higgs, H. (2015). Discouraged finance seekers: An analysis of Australian small and medium-sized enterprises. International Small Business Journal, 33(7), 689-707. https://doi.org/10.1177/02662 42613516138

Zhou, K. Z., \& Li, C. B. (2012). How knowledge affects radical innovation: Knowledge base, market knowledge acquisition, and internal knowledge sharing. Strategic Management Journal, 33(9), 1090-1102. https://doi.org/10.1002/smj.1959

Publisher's note Springer Nature remains neutral with regard to jurisdictional claims in published maps and institutional affiliations. 